\title{
Synthesis, Biological Evaluation, and Molecular Modeling of Aza-Crown Ethers
}

\author{
Stepan S. Basok ${ }^{1,+}$, Igor A. Schepetkin ${ }^{2,+}$, Andrei I. Khlebnikov ${ }^{3}$ (D) Anatoliy F. Lutsyuk ${ }^{1}$ (D), \\ Tatiana I. Kirichenko ${ }^{1}$, Liliya N. Kirpotina ${ }^{2}$, Victor I. Pavlovsky ${ }^{3,4}$, Klim A. Leonov ${ }^{4}$, \\ Darya A. Vishenkova ${ }^{3}$ and Mark T. Quinn ${ }^{2, *(D)}$
}

check for updates

Citation: Basok, S.S.; Schepetkin, I.A.; Khlebnikov, A.I.; Lutsyuk, A.F.; Kirichenko, T.I.; Kirpotina, L.N.;

Pavlovsky, V.I.; Leonov, K.A.;

Vishenkova, D.A.; Quinn, M.T.

Synthesis, Biological Evaluation, and Molecular Modeling of Aza-Crown Ethers. Molecules 2021, 26, 2225. https://doi.org/10.3390/ molecules 26082225

Academic Editor: Teobald Kupka

Received: 12 March 2021

Accepted: 7 April 2021

Published: 12 April 2021

Publisher's Note: MDPI stays neutral with regard to jurisdictional claims in published maps and institutional affiliations.

Copyright: (C) 2021 by the authors Licensee MDPI, Basel, Switzerland. This article is an open access article distributed under the terms and conditions of the Creative Commons Attribution (CC BY) license (https:// creativecommons.org/licenses/by/ $4.0 /)$.
1 A.V. Bogatsky Physico-Chemical Institute of National Academy of Science of Ukraine, 65080 Odessa, Ukraine stepan_basok@ukr.net (S.S.B.); lutsyuk@ukr.net (A.F.L.); ti.kirichenko@ukr.net (T.I.K.)

2 Department of Microbiology and Cell Biology, Montana State University, Bozeman, MT 59717, USA; schepetkin@yahoo.com (I.A.S.); liliya.kirpotina@montana.edu (L.N.K.)

3 Kizhner Research Center, National Research Tomsk Polytechnic University, Tomsk 634050, Russia; aikhl@chem.org.ru (A.I.K.); victor_pavlovsky@mail.ru (V.I.P.); vishenkova_darya@mail.ru (D.A.V.)

4 Innovative Pharmacology Research, LLC, Tomsk 634021, Russia; leonov_k90@mail.ru

* Correspondence: mquinn@montana.edu; Tel.: +406-994-4707; Fax: +406-994-4303

+ These authors contributed equally to this research.

\begin{abstract}
Synthetic and natural ionophores have been developed to catalyze ion transport and have been shown to exhibit a variety of biological effects. We synthesized 24 aza- and diaza-crown ethers containing adamantyl, adamantylalkyl, aminomethylbenzoyl, and $\varepsilon$-aminocaproyl substituents and analyzed their biological effects in vitro. Ten of the compounds $(\mathbf{8}, \mathbf{1 0}-\mathbf{1 7}$, and $\mathbf{2 1})$ increased intracellular calcium $\left(\left[\mathrm{Ca}^{2+}\right]_{\mathrm{i}}\right)$ in human neutrophils, with the most potent being compound 15 (N,N'-bis[2-(1-adamantyl)acetyl]-4,10-diaza-15-crown-5), suggesting that these compounds could alter normal neutrophil $\left[\mathrm{Ca}^{2+}\right]_{i}$ flux. Indeed, a number of these compounds (i.e., 8, 10-17, and 21) inhibited $\left[\mathrm{Ca}^{2+}\right]_{\mathrm{i}}$ flux in human neutrophils activated by $N$-formyl peptide ( $\mathrm{MLF}$ ). Some of these compounds also inhibited chemotactic peptide-induced $\left[\mathrm{Ca}^{2+}\right]_{\mathrm{i}}$ flux in HL60 cells transfected with $\mathrm{N}$-formyl peptide receptor 1 or 2 (FPR1 or FPR2). In addition, several of the active compounds inhibited neutrophil reactive oxygen species production induced by phorbol 12-myristate 13-acetate (PMA) and neutrophil chemotaxis toward $f \mathrm{MLF}$, as both of these processes are highly dependent on regulated $\left[\mathrm{Ca}^{2+}\right]_{i}$ flux. Quantum chemical calculations were performed on five structure-related diaza-crown ethers and their complexes with $\mathrm{Ca}^{2+}, \mathrm{Na}^{+}$, and $\mathrm{K}^{+}$to obtain a set of molecular electronic properties and to correlate these properties with biological activity. According to density-functional theory (DFT) modeling, $\mathrm{Ca}^{2+}$ ions were more effectively bound by these compounds versus $\mathrm{Na}^{+}$ and $\mathrm{K}^{+}$. The DFT-optimized structures of the ligand- $\mathrm{Ca}^{2+}$ complexes and quantitative structureactivity relationship (QSAR) analysis showed that the carbonyl oxygen atoms of the $N, N^{\prime}$-diacylated diaza-crown ethers participated in cation binding and could play an important role in $\mathrm{Ca}^{2+}$ transfer. Thus, our modeling experiments provide a molecular basis to explain at least part of the ionophore mechanism of biological action of aza-crown ethers.
\end{abstract}

Keywords: aza-crown ether; neutrophil; ionophore; density-functional theory (DFT); quantitative structure-activity relationship (QSAR) modeling

\section{Introduction}

Crown ethers are macrocyclic polyethers containing three to twenty oxygen atoms separated by two or more carbon atoms, which can be either substituted or unsubstituted. Structurally, crown ethers possess a hydrophobic ring surrounding a hydrophilic cavity, which enables them to form stable complexes with metal ions, and at the same time to be incorporated in the lipid fraction of the cell membrane. Consequently, they exhibit ionophore properties by facilitating ion transport across membranes down their 
electrochemical gradients [1]. Thus, they behave similarly to natural ionophores, such as valinomycin, nigericin, and monensin.

Since the discovery of the crown ethers over 50 years ago [2], the chemistry of synthetic macrocycles for highly selective, structure-specific, supramolecular (host/guest) complexation has experienced rapid development for various applications, including the development of optically active sensors and mobile ion carriers [3-6]. Synthetic ionophores or carriers have also been developed as simplified models to study the driving factors for ion translocation. For example, a variety of tailored crown ethers have been successfully used as molecular transporters that span the lipid bilayer (e.g., [7]). These macrocycles are exceptionally versatile and can selectively bind to a range of metal ions and a variety of neutral and ionic organic species [8,9].

Crown ethers also have potential in the development of novel therapeutics. For example, crown ethers with antitumor activity include DNA intercalators and actinomycin D $[10,11]$. Aza- and diaza-crown ethers are of particular interest because their biological properties can be modified by introducing various substituents on their nitrogen atoms. For example, complexes of diaza-18-crown- 6 with salts of arylchalcogen acetic acids, as well as glycyl derivatives of diaza-18-crown-6, have been shown to exhibit antiproliferative activity $[12,13]$. Likewise, benzodiaza-15-crown- 5 compounds containing two carboxymethyl or 3-(carboxy)prop-1-yl substituents on their nitrogen atoms were antimutagenic [14]. Addition of an adamantyl group to diaza-18-crown-6 resulted in optimal membrane permeability and conformational constraint for efficient transport through lipid membranes [15], facilitating its antitumor activity $[16,17]$.

Crown ether derivatives have also been reported to exhibit other biological properties. For example, complexes of diaza-crown ethers with $\mathrm{Fe}_{3} \mathrm{O}_{4}$ have been shown to be active against Gram-positive and Gram-negative microorganisms [18]. Likewise, diaza-18-crown6 lariate compounds have been shown to have antimicrobial activity and also significantly increase the effectiveness of rifampicin and tetracycline $[19,20]$. Benzyl derivatives of diaza-18-crown-6 ethers have been shown to exhibit cardiotropic effects [21], whereas naphthyl derivatives of diaza-crown ethers have been shown to have hematopoietic and colony-stimulating activity [22]. Moreover, some aza-15-crown-5 ether derivatives have been reported to have nootropic, antihypoxic, antiamnesic, and antiviral activities [23-26].

Little information regarding the immunomodulatory activity of crown ethers has been reported, aside from one publication indicating that dibenzo-18-crown- 6 ethers have antiinflammatory activity [27]. On the other hand, the natural ionophores valinomycin, nigericin, and monensin have been shown to modulate neutrophil functional activity [28-33]. Here, we elucidated the biological activity of structurally related adamantyl-containing aza- and diazacrown compounds and found that they elevated the cytosolic $\mathrm{Ca}^{2+}$ concentrations $\left(\left[\mathrm{Ca}^{2+}\right]_{\mathrm{i}}\right)$ in human neutrophils and also modulated $N$-formyl peptide receptor (FPR)-dependent functional activity. Quantum chemical calculations and molecular modeling were performed on five structurally-related diaza-crown ethers and their complexes with $\mathrm{Ca}^{2+}, \mathrm{Na}^{+}$, and $\mathrm{K}^{+}$to obtain a set of molecular electronic properties and to correlate these properties with biological activity.

\section{Results and Discussion}

\subsection{Synthesis of Crown Ethers}

The investigated compounds were synthesized according to Schemes 1-7. Adamantylamides 1-4 were synthesized by acylation of the corresponding amines with adamantane$\mathrm{t}$-carbonyl chloride in anhydrous chloroform in the presence of trimethylamine $\left(\mathrm{Et}_{3} \mathrm{~N}\right)$ (Scheme 1). 


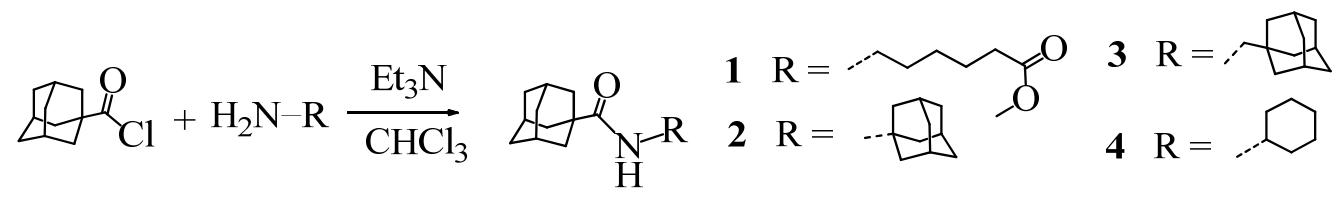

Scheme 1. General method for the synthesis of adamantylamides 1-4.

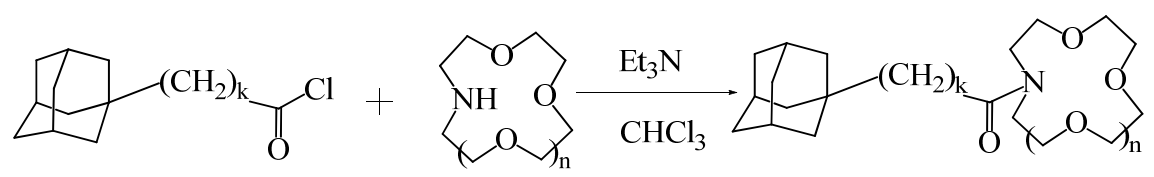

$5(\mathrm{k}=0, \mathrm{n}=1) ; 8(\mathrm{k}=1, \mathrm{n}=2) ;$ $\mathbf{6}(\mathrm{k}=0, \mathrm{n}=2) ; 9(\mathrm{k}=1, \mathrm{n}=3)$.

$7(\mathrm{k}=0, \mathrm{n}=3)$;

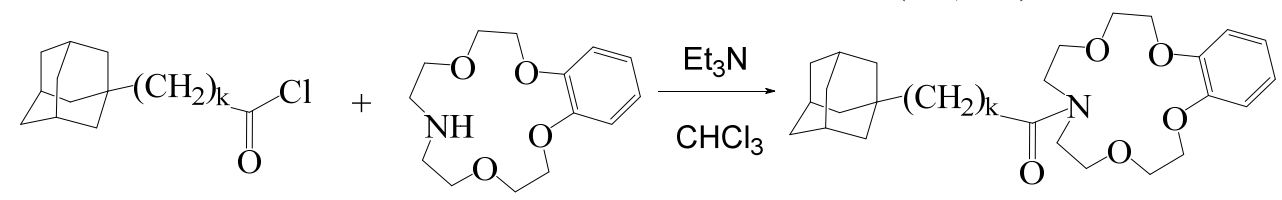

$10(\mathrm{k}=0) ; 11(\mathrm{k}=1)$.

Scheme 2. General method for the synthesis of macrocyclic adamantylamides 5-11.

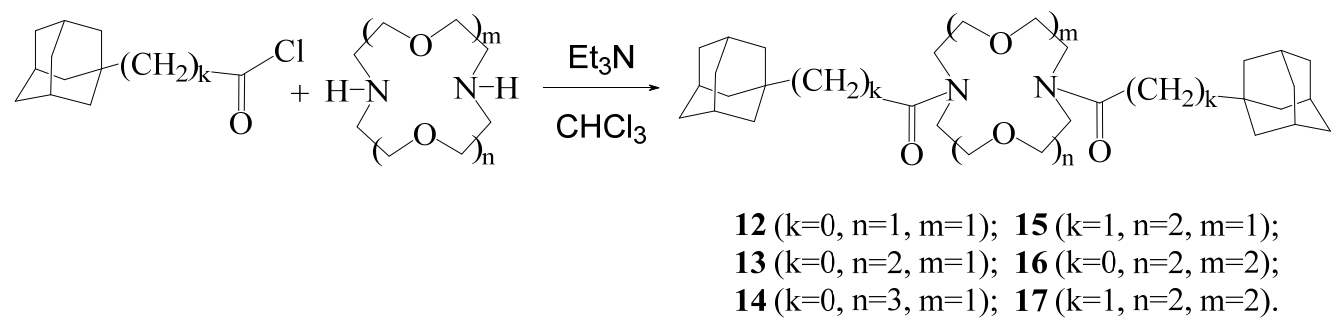

Scheme 3. General method for the synthesis of diacyl derivatives 12-17.<smiles>CC(C)(C)C1(CCOCCOCCOCCOCCNC(=O)C23CC4CC(C2)C(C4)C3)CC1</smiles>

6

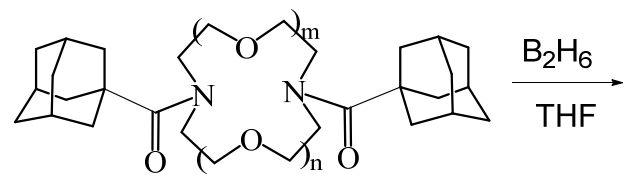

$13(\mathrm{n}=2, \mathrm{~m}=1)$; $16(\mathrm{n}=2, \mathrm{~m}=2)$

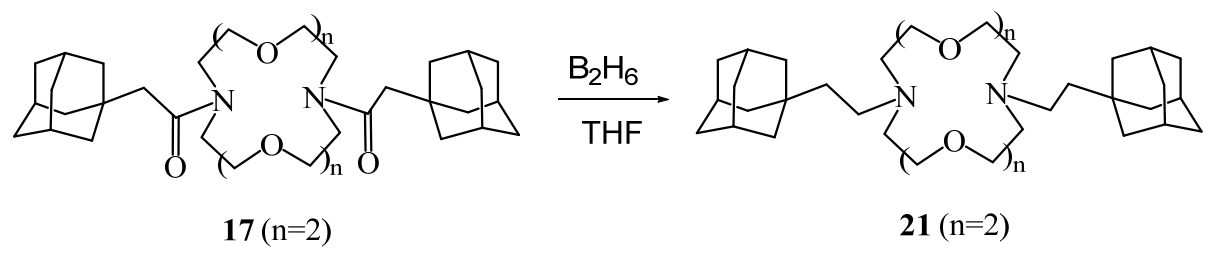

Scheme 4. General method for the synthesis of adamantylalkyl derivatives 18-21. 


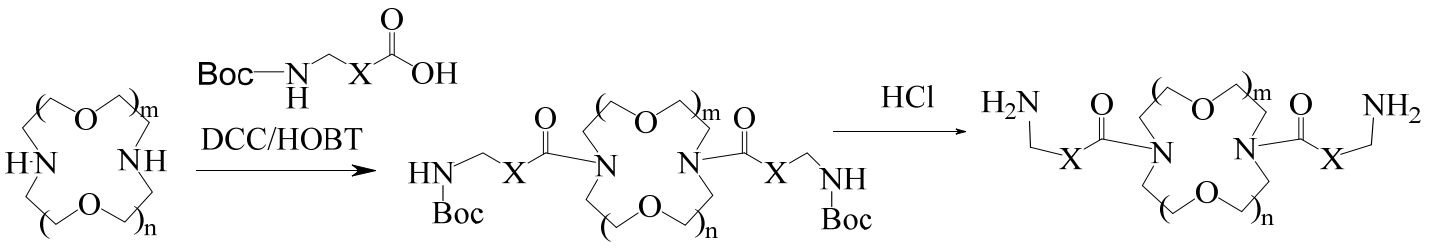

$$
\begin{aligned}
& 22\left(\mathrm{n}=2, \mathrm{~m}=1, \mathrm{X}=\left(\mathrm{CH}_{2}\right)_{4}\right) \text {; } \\
& 23\left(\mathrm{n}=1, \mathrm{~m}=1, \mathrm{X}=\left(\mathrm{CH}_{2}\right)_{4}\right) \text {; } \\
& 24\left(\mathrm{n}=2, \mathrm{~m}=2, \mathrm{X}=p-\mathrm{C}_{6} \mathrm{H}_{4}\right) \text {. }
\end{aligned}
$$

Scheme 5. General method for the synthesis of diacyl derivatives 22-24.

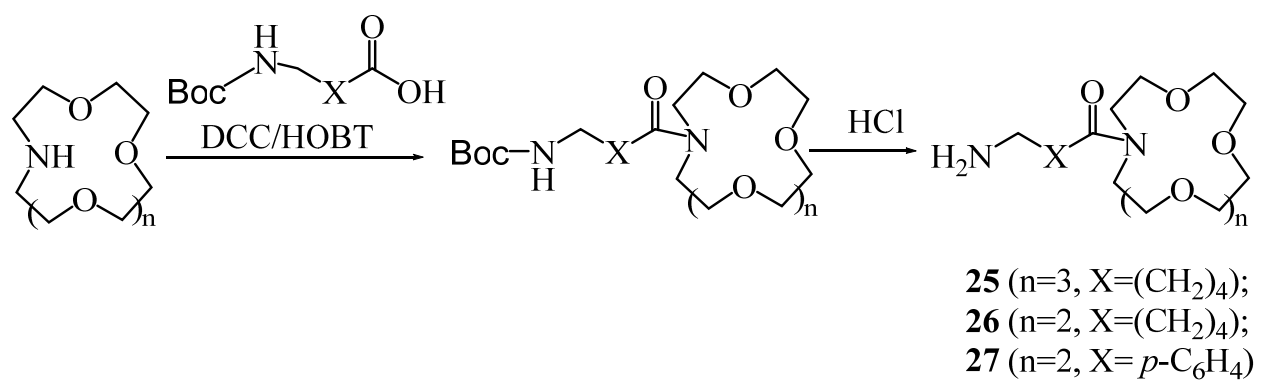

Scheme 6. General method for the synthesis of monoacyl derivatives 25-27.

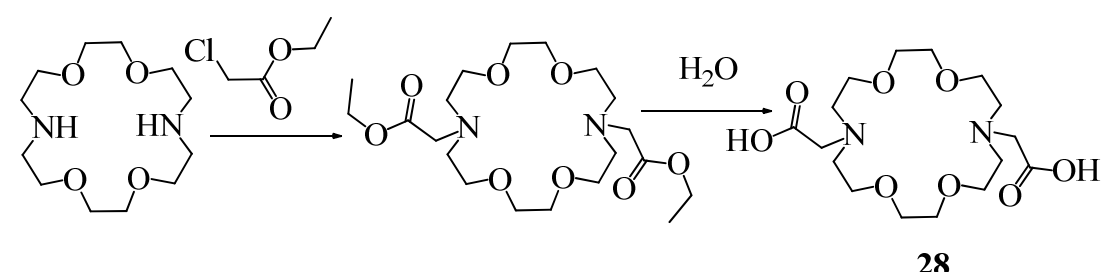

Scheme 7. Synthesis of $N, N^{\prime}$-bis(carboxymethyl)-4,13-diaza-18-crown-6 (28).

Macrocyclic adamantylamides 5-11 were synthesized by acylation of the corresponding monoaza-crown ether with adamantane-1-carbonyl chloride or 2-(adamantan-1-yl)acetyl chloride in anhydrous chloroform in the presence of triethylamine (Scheme 2).

Derivatives of diaza-crown ethers 12-17 were obtained by acylation of amino groups with adamantane-1-carbonyl chloride or 2-(adamantan-1-yl)acetyl chloride in anhydrous chloroform in the presence of triethylamine (Scheme 3).

Adamantylalkyl derivatives of diaza-crown ethers 18-21 were obtained by reduction of previously synthesized macrocyclic amides $6,13,16,17$ with diborane in tetrahydrofuran (THF) (Scheme 4).

Diacyl derivatives of diaza-crown ethers 22-24 were obtained by the carbodiimide method in the presence of hydroxybenzotriazole (HOBT), followed by removal of the tert-butoxycarbonyl (Boc) protecting group with $\mathrm{HCl}$ (Scheme 5).

Monoacyl derivatives $\mathbf{2 5 - 2 7}$ of aza-crown ethers were synthesized in a similar way (Scheme 6).

$N, N^{\prime}$-bis(Carboxymethyl)-4,13-diaza-18-crown-6 (28) was obtained by alkylation of 4,13-diaza-18-crown- 6 with chloroacetic acid ethyl ester in the presence of triethylamine, followed by hydrolysis [34] (Scheme 7).

\subsection{Biological Activity of Aza-Crown Ethers}

We screened 24 aza- and diaza-crown ethers with adamantyl, adamantylalkyl, aminom ethylbenzoyl, and $\varepsilon$-aminocaproyl substituents for their $\mathrm{Ca}^{2+}$ ionophore effects in human neutrophils. To monitor cytoplasmic $\mathrm{Ca}^{2+}$ levels, we used the fluorescent $\mathrm{Ca}^{2+}$ indicator Fluo-4, which is a dynamic single-wavelength fluorescent $\mathrm{Ca}^{2+}$ indicator. Increases in fluorescence intensity $\left(\lambda_{\mathrm{ex}}=485 \mathrm{~nm}, \lambda_{\mathrm{em}}=538 \mathrm{~nm}\right)$ reflect the rise in cytoplasmic $\mathrm{Ca}^{2+}$ 
concentrations $\left(\left[\mathrm{Ca}^{2+}\right]_{\mathrm{i}}\right.$; see Materials and Methods). We found that treatment with ten of the compounds $\left(\mathbf{8}, \mathbf{1 0}-\mathbf{1 7}\right.$, and 21) elevated $\left[\mathrm{Ca}^{2+}\right]_{i}$ in human neutrophils, with the most potent being compound 15 (N,N'-bis[2-(1-adamantyl)acetyl]-4,10-diaza-15-crown-5), which had an $\mathrm{EC}_{50}$ of $4.7 \mu \mathrm{M}$ (Table 1). Compound 15 had very high efficacy, inducing a response similar in amplitude to that induced by the neutrophil agonist $f$ MLF, while compounds 8 , 10-14, 16, 17, and 21 were less effective (25-50\% of the response induced by $5 \mathrm{nM} f \mathrm{MLF}$ ). A representative time course for the elevation of neutrophil $\left[\mathrm{Ca}^{2+}\right]_{i}$ by compound 15 is shown in Figure 1.

Table 1. Effect of aza- and diaza-crown ethers on $\left[\mathrm{Ca}^{2+}\right]_{\mathrm{i}}$ flux in human neutrophils.

\begin{tabular}{|c|c|}
\hline Compound & $\mathrm{EC}_{50}(\mu \mathrm{M})($ Efficacy, \%) \\
\hline 5 & N.A. \\
\hline 6 & N.A. \\
\hline 7 & N.A. \\
\hline 8 & $22.4 \pm 4.3(50)$ \\
\hline 9 & N.A. \\
\hline 10 & $9.7 \pm 2.6(35)$ \\
\hline 11 & $15.6 \pm 4.4(40)$ \\
\hline 12 & $23.8 \pm 7.6(25)$ \\
\hline 13 & $6.9 \pm 2.1(25)$ \\
\hline 14 & $9.5 \pm 2.7(40)$ \\
\hline 15 & $4.7 \pm 1.5(110)$ \\
\hline 16 & $15.7 \pm 3.8(25)$ \\
\hline 17 & $15.9 \pm 2.5(50)$ \\
\hline 18 & N.A. \\
\hline 19 & N.A. \\
\hline 20 & N.A. \\
\hline 21 & $11.3 \pm 3.1(40)$ \\
\hline 22 & N.A. \\
\hline 23 & N.A. \\
\hline 24 & N.A. \\
\hline 25 & N.A. \\
\hline 26 & N.A. \\
\hline 27 & N.A. \\
\hline 28 & N.A. \\
\hline
\end{tabular}

N.A., no activity was found at concentration $<50 \mu \mathrm{M}$. Efficacy (in parentheses) is expressed as $\%$ of the response induced by $5 \mathrm{nM} f \mathrm{MLF}$. 


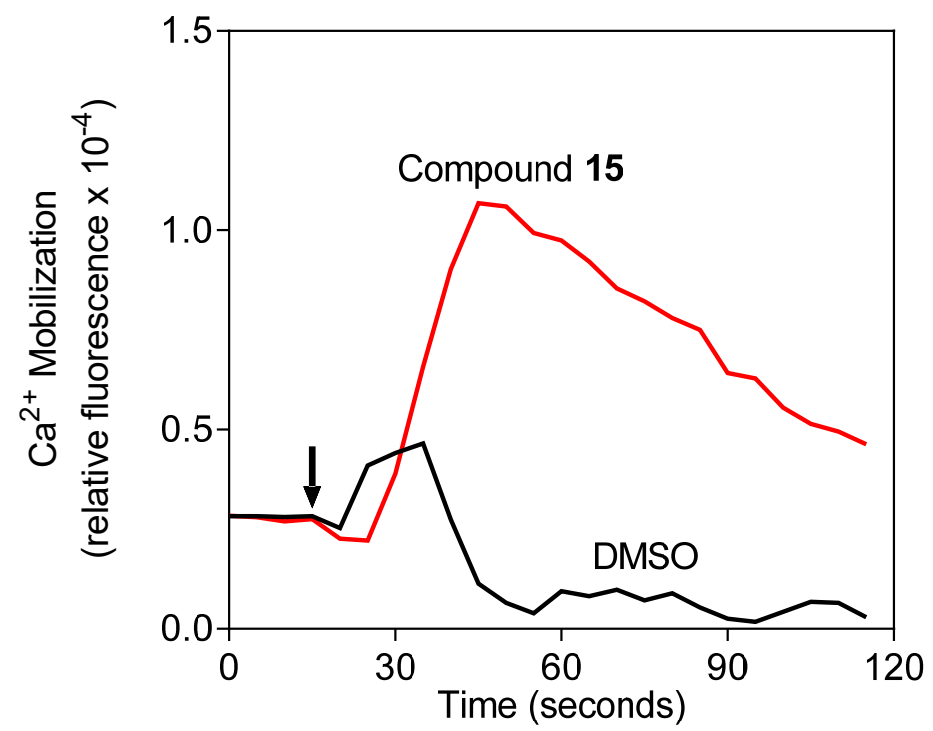

Figure 1. Effect of compound 15 on $\left[\mathrm{Ca}^{2+}\right]_{i}$ in human neutrophils. Human neutrophils were treated with $5 \mu \mathrm{M}$ of compound 15 or $1 \%$ dimethyl sulfoxide (DMSO) (negative control) and $\left[\mathrm{Ca}^{2+}\right]_{\mathrm{i}}$ was monitored (arrow indicates addition of treatment). Three independent experiments were performed, and all had similar results. The data shown are from one of these experiments.

Although compounds 16, 17, 20, 21, 24, and 28 all have diaza-18-crown-6 structures, only 16, 17, and 21 were active. Similarly, compounds 13, 15, 19, and 22 all have diaza-15crown-5 structures, whereas only $\mathbf{1 3}$ and $\mathbf{1 5}$ were active. Thus, it is evident from these data that the nature of additional substituents can affect $\mathrm{Ca}^{2+}$ binding and (or) transportation through cell membranes.

Since these compounds elevated neutrophil $\left[\mathrm{Ca}^{2+}\right]_{i}$, and cytosolic $\mathrm{Ca}^{2+}$ flux is a key component of neutrophil activation [35,36], we evaluated if they could alter neutrophil activation by FPR1 or FPR2 agonists. Neutrophils and FPR-transfected HL60 cells were preincubated for $10 \mathrm{~min}$ with crown ether compounds, and $\left[\mathrm{Ca}^{2+}\right]_{i}$ flux was stimulated with either an FPR1 agonist ( $f$ MLF for human neutrophils and FPR1-HL60 cells) or an FPR2 agonist (WKYMVM for FPR2-HL60 cells). We found that compounds 8, 10, 13-17, and 21 inhibited the $f$ MLF-induced increase in $\left[\mathrm{Ca}^{2+}\right]_{\mathrm{i}}$ in human neutrophils (Table 2), and a representative concentration-dependent response for the inhibition of the $f$ MLF-induced increase in neutrophil $\left[\mathrm{Ca}^{2+}\right]_{i}$ by compound 15 is shown in Figure 2A. 
Table 2. Effect of aza- and diaza-crown ethers on N-formyl peptide receptor 1 or 2 (FPR1/FPR2) agonist-induced Ca ${ }^{2+}$ influx in human neutrophils and FPR-transfected HL60 cells and phorbol 12-myristate 13-acetate (PMA)-induced neutrophil reactive oxygen species (ROS) production.

\begin{tabular}{|c|c|c|c|c|}
\hline \multirow[b]{2}{*}{ Compound } & \multicolumn{3}{|c|}{ FPR1/FPR2 Agonist-Induced $\Delta\left[\mathrm{Ca}^{2+}\right]_{i}$} & \multirow{2}{*}{$\begin{array}{l}\text { PMA-Induced } \\
\text { ROS Production } \\
\text { IC }_{50}(\mu \mathrm{M})\end{array}$} \\
\hline & $\begin{array}{l}\text { Neutrophils } \\
\text { IC }_{50}(\mu \mathrm{M})\end{array}$ & $\begin{array}{c}\text { FPR1-HL60 } \\
\text { IC }_{50}(\mu \mathrm{M})\end{array}$ & $\begin{array}{c}\text { FPR2-HL60 } \\
\text { IC }_{50}(\mu \mathrm{M})\end{array}$ & \\
\hline 5 & N.A. & N.A. & N.A. & N.A. \\
\hline 6 & N.A. & N.A. & N.A. & N.A. \\
\hline 7 & N.A. & N.A. & N.A. & N.A. \\
\hline 8 & $2.6 \pm 0.4$ & $37.1 \pm 4.8$ & N.A. & N.A. \\
\hline 9 & N.A. & N.A. & N.A. & N.A. \\
\hline 10 & $11.2 \pm 2.7$ & $12.2 \pm 1.9$ & $36.4 \pm 5.6$ & N.A. \\
\hline 11 & $9.4 \pm 0.6$ & N.A. & $29.1 \pm 3.2$ & N.A. \\
\hline 12 & $4.0 \pm 1.4$ & N.A. & N.A. & N.A. \\
\hline 13 & $7.4 \pm 1.3$ & $16.5 \pm 3.2$ & $32.6 \pm 4.5$ & $25.9 \pm 2.7$ \\
\hline 14 & $3.5 \pm 0.4$ & $11.6 \pm 2.1$ & $8.3 \pm 2.3$ & $21.9 \pm 2.2$ \\
\hline 15 & $4.1 \pm 0.6$ & $4.8 \pm 0.9$ & $7.2 \pm 1.7$ & $4.1 \pm 0.1$ \\
\hline 16 & $3.4 \pm 0.8$ & $7.3 \pm 2.6$ & $30.7 \pm 6.4$ & N.A. \\
\hline 17 & $1.5 \pm 0.4$ & $3.7 \pm 0.7$ & $7.6 \pm 1.9$ & $8.2 \pm 0.1$ \\
\hline 18 & N.A. & N.A. & N.A. & N.A. \\
\hline 19 & N.A. & N.A. & N.A. & N.A. \\
\hline 20 & N.A. & N.A. & N.A. & N.A. \\
\hline 21 & $10.2 \pm 2.6$ & $9.6 \pm 2.1$ & $28.2 \pm 2.6$ & $15.3 \pm 1.8$ \\
\hline 22 & N.A. & N.A. & N.A. & N.A. \\
\hline 23 & N.A. & N.A. & N.A. & N.A. \\
\hline 24 & N.A. & N.A. & N.A. & N.A. \\
\hline 25 & N.A. & N.A. & N.A. & N.A. \\
\hline 26 & N.A. & N.A. & N.A. & N.A. \\
\hline 27 & N.A. & N.A. & N.A. & N.A. \\
\hline 28 & N.A. & N.A. & N.A. & N.A. \\
\hline
\end{tabular}

N.A., no activity was found at concentration $<50 \mu \mathrm{M}$. 

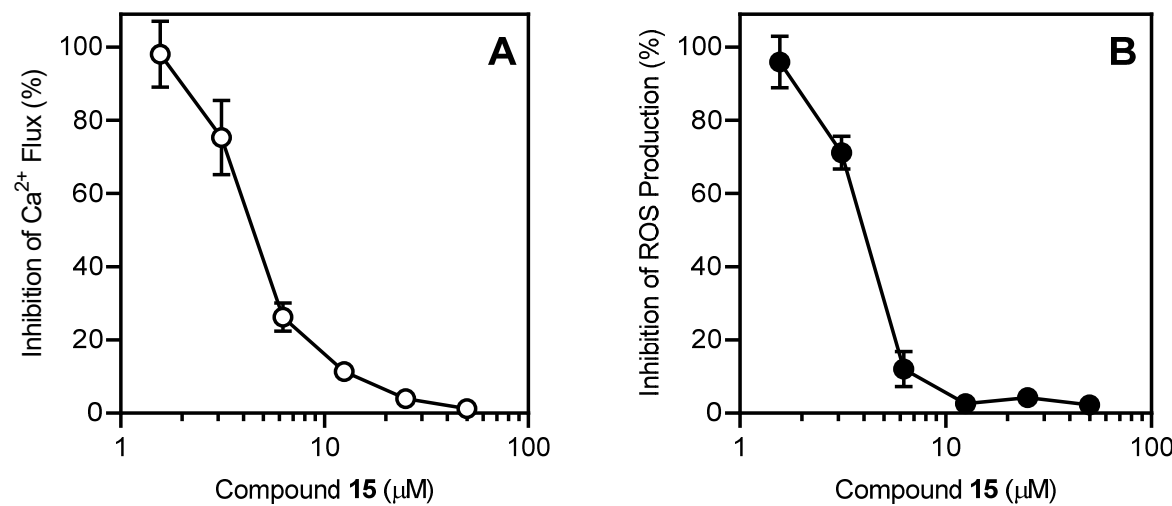

Figure 2. Inhibitory effect of compound $\mathbf{1 5}$ on $\mathrm{Ca}^{2+}$ mobilization and ROS production in human neutrophils. (A) Human neutrophils were treated with the indicated concentrations of compound 15 or $1 \%$ DMSO (negative control) for $10 \mathrm{~min}$. The cells were activated by $5 \mathrm{nM} f \mathrm{MLF}$, and $\left[\mathrm{Ca}^{2+}\right]_{\mathrm{i}}$ was monitored, as described. (B) Human neutrophils were treated with the indicated concentrations of compound 15 or $1 \%$ DMSO (negative control) for $10 \mathrm{~min}$. The cells were activated by $200 \mathrm{nM}$ PMA, and ROS production was monitored, as described. For each panel, the data are presented as the mean \pm S.D. $(N=3)$ from one experiment that is representative of three independent experiments.

Compounds 8, 10, 13-17, and 21 also inhibited the $f$ MLF-induced increase in $\left[\mathrm{Ca}^{2+}\right]_{\mathrm{i}}$ in FPR1-HL60 cells and the WKYMVM-induced increase in [Ca $\left.{ }^{2+}\right]_{i}$ in FPR2-HL60 cells (Table 1), indicating that these compounds disrupted $\mathrm{Ca}^{2+}$ mobilization induced by these G protein-coupled receptor (GPCR) peptide agonists. Note that three of the compounds that inhibited neutrophil $\left[\mathrm{Ca}^{2+}\right]_{i}$ flux induced by the peptide agonist (see Table 1) had much higher $\mathrm{IC}_{50}$ values and targeted only one FPR subtype in transfected HL60 cells (compounds 8 and 11) or had no effect at either receptor (compound 12). It is not clear why FPR-transfected HL60 cells responded differently to these compounds. It is possible that this is due to differences in neutrophils and HL60 cells and will require further investigation.

To further investigate the effects of the most active crown ethers (those with $\mathrm{IC}_{50}<10 \mu \mathrm{M}$ ), we analyzed the effects of compounds $\mathbf{8}$ and 11-17 on neutrophil chemotaxis. All eight of these compounds inhibited $f$ MLF-induced neutrophil chemotaxis, with $\mathrm{IC}_{50}$ values ranging from 5 to $16 \mu \mathrm{M}$ (Table 3), indicating that their effect on cytosolic $\mathrm{Ca}^{2+}$ was sufficient to inhibit neutrophil activation.

Table 3. Inhibitory effect of selected crown ethers on neutrophil chemotactic activity.

\begin{tabular}{cc}
\hline Compound & Chemotaxis, IC $_{50,} \boldsymbol{\mu M}$ \\
\hline $\mathbf{8}$ & $13.2 \pm 3.8$ \\
\hline $\mathbf{1 1}$ & $12.8 \pm 5.3$ \\
\hline $\mathbf{1 2}$ & $15.7 \pm 4.2$ \\
\hline $\mathbf{1 3}$ & $5.8 \pm 1.4$ \\
\hline $\mathbf{1 4}$ & $6.1 \pm 2.1$ \\
\hline $\mathbf{1 5}$ & $5.7 \pm 0.2$ \\
\hline $\mathbf{1 6}$ & $5.3 \pm 0.4$ \\
\hline $\mathbf{1 7}$ & $5.2 \pm 1.7$ \\
\hline
\end{tabular}

The most potent and receptor-specific FPR1 ligands described so far are the macrocyclic peptides, cyclosporines A and $\mathrm{H}$ [37]. Thus, we evaluated if our active macrocyclic aza-crown compounds might be binding to and blocking FPR1. The three most potent compounds (13-15) were analyzed for their ability to compete with WKYMVm-FITC 
for binding to FPR1, as described previously [38]. However, none of these compounds competed with WKYMVm-FITC and thus likely do not bind directly to FPR1.

To evaluate if the crown ethers could also disrupt GPCR-independent functional activity, we evaluated the effects of these compounds on phorbol 12-myristate 13-acetate (PMA)-stimulated reactive oxygen species (ROS) production. We found that compounds 13-15, 17, and 21 inhibited ROS production in human neutrophils, with the most potent being compound 15 , which had an $\mathrm{IC}_{50}$ of $4.1 \mu \mathrm{M}$ (Table 2). A representative concentrationdependent response for the inhibition of PMA-stimulated neutrophil ROS production by compound 15 is shown in Figure 2B. Since ROS production in neutrophils also requires increased $\left[\mathrm{Ca}^{2+}\right]_{i}[39,40]$, the results again confirm that the impact of these compounds on $\mathrm{Ca}^{2+}$ flux kinetics can alter neutrophil function.

To ensure that the results on inhibitory activity of the crown ethers were not due to possible compound toxicity, cytotoxicity of the active compounds was evaluated at various concentrations up to $25 \mu \mathrm{M}$ in wild-type HL60 cells during a 90-min incubation period. None of the tested compounds affected cell viability at the highest tested concentrations (data not shown), thereby verifying that these compounds were not cytotoxic, at least during this relatively short incubation period.

Thus, our biological data indicate that the size of the macrocycle (compare compounds 8 and 9) and the structure of the side chains (compare compounds 13 and 19) both influence biological activity of the crown ethers. To characterize molecular conformations and electronic parameters of selected compounds, we performed molecular modeling.

\subsection{Molecular Modeling}

Several crown ethers have been reported to be ionophores with various selectivity for alkali metal cations $[17,41,42]$. We performed density-functional theory (DFT) modeling of the interaction between selected diaza-crown ethers and several cations $\left(\mathrm{Na}^{+}, \mathrm{K}^{+}, \mathrm{Ca}^{2+}\right)$ by evaluating their geometries and binding energies. Compounds $\mathbf{1 2 - 1 5}$, and $\mathbf{1 9}$, were chosen for molecular modeling in order to consider the effects of differences in ring sizes, the presence/absence of $\mathrm{C}=\mathrm{O}$ groups, and differences in $\mathrm{CH}_{2}$ linkers attached to the adamantane moiety. To correctly calculate the energy of complex formation, it was necessary to perform a thorough conformational analysis of these macrocyclic ligands. We performed a systematic conformational search using molecular mechanics with subsequent optimization of the selected conformers by the semiempirical PM3 method. In addition, we employed a more accurate DFT method for individual low-energy conformers to find the optimal geometry for each of the aza-crown ethers. As shown in Figure 3, all heteroatoms of macrocycles 12-15, together with both carbonyl oxygen atoms, formed a cavity that could potentially be capable of capturing positively charged ions. In the anti-orientation, one of the carbonyl oxygen atoms of molecule $\mathbf{1 3}$ is directed towards the shorter segment of the macrocycle, and the other one is oriented towards the longer segment (anti-oriented carbonyl groups are shown by arrows in Figure 3). 


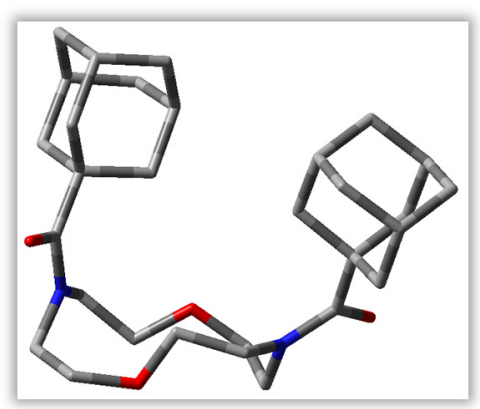

Compound 12

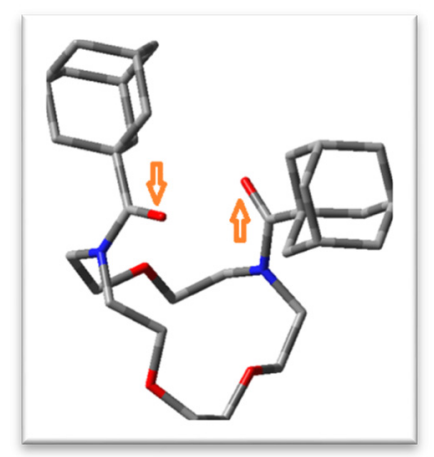

Compound 13

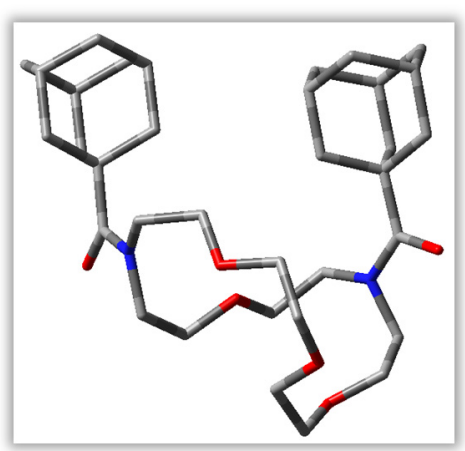

Compound 14

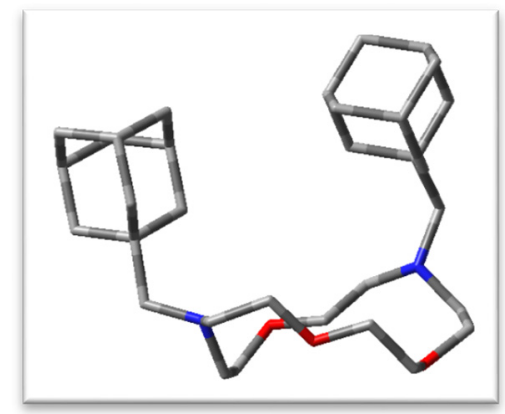

Compound 19

Figure 3. The low-energy conformers of compounds 12-15, and 19, according to density-functional theory (DFT) calculations with the BLYP functional. Hydrogen atoms are not shown. Carbonyl oxygen atoms in anti-orientation for the conformer of compound $\mathbf{1 3}$ are indicated with orange arrows.

The conformation in which both carbonyl oxygen atoms of $\mathbf{1 3}$ are syn-oriented toward the shorter segment was also characterized by a favorable arrangement of all seven heteroatoms for cation capture. This conformation had a higher energy and was not present among the 30 pre-optimal conformations initially selected by molecular mechanics. Nevertheless, the possibility of complex formation with a ligand having the aforementioned syn-orientation of carbonyl groups was also considered. Similarly, the possibility of metal ion complexation with the compound containing these groups in anti-and synorientations was considered for diaza-crown ethers 12, 14 (anti-oriented carbonyl groups in the lowest-energy conformation), and $\mathbf{1 5}$ (the most stable conformer with syn-oriented carbonyl groups) (Figure 3). Additionally, we considered the possibility of adopting a trans-orientation for the two adamantyl-containing substituents with their locations on opposite sides of the median plane of the macrocycle in the flexible ligand $\mathbf{1 4}$.

$\mathrm{Na}^{+}, \mathrm{K}^{+}$, and $\mathrm{Ca}^{2+}$ ions were introduced into the central part of the conformer of compound 19, as well as into the syn- and anti-conformers of 12-15 (for ligand $\mathbf{1 4}$ also into the trans-conformation), and the structures of the complexes were optimized by DFT modeling in the same approximation that was used for the diaza-crown ethers. The optimal geometric structures of the complexes are shown in Figure 4. 


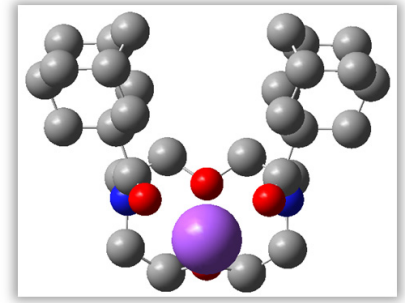

Compound $12+\mathrm{Na}^{+}$

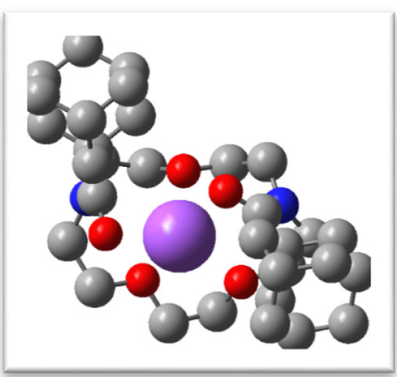

Compound $13+\mathrm{Na}^{+}$

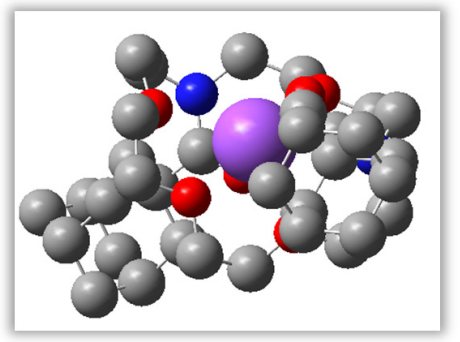

Compound $14+\mathrm{Na}^{+}$

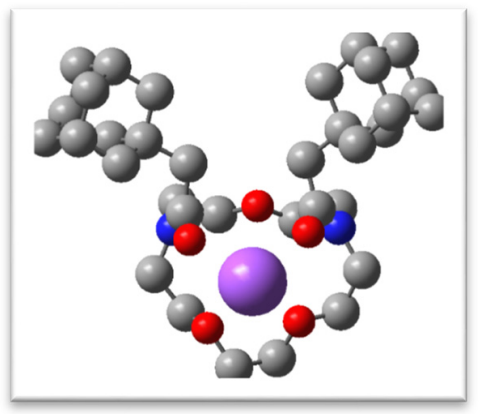

Compound $15+\mathrm{Na}^{+}$

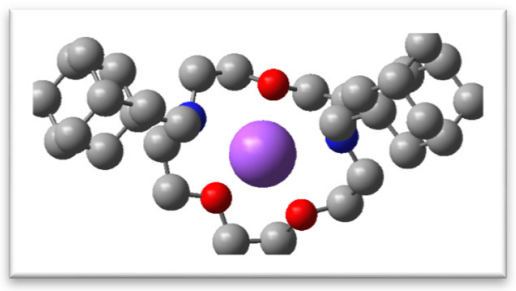

Compound $19+\mathrm{Na}^{+}$

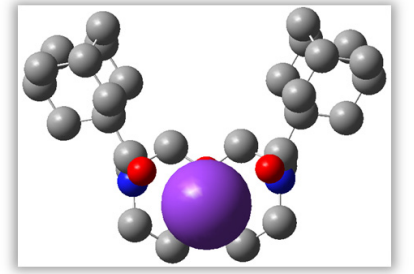

Compound $12+\mathrm{K}^{+}$

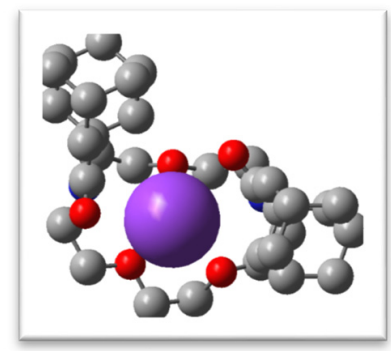

Compound $13+\mathrm{K}^{+}$

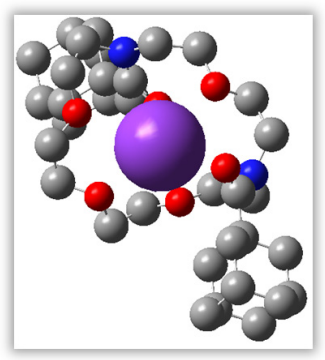

Compound $14+\mathrm{K}^{+}$

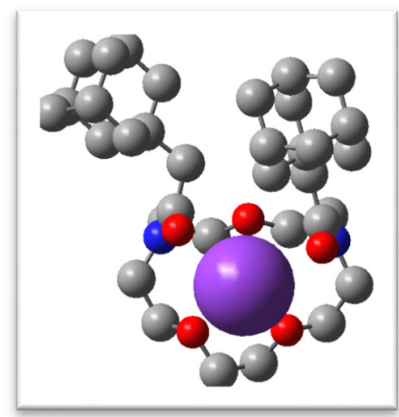

Compound $15+\mathrm{K}^{+}$

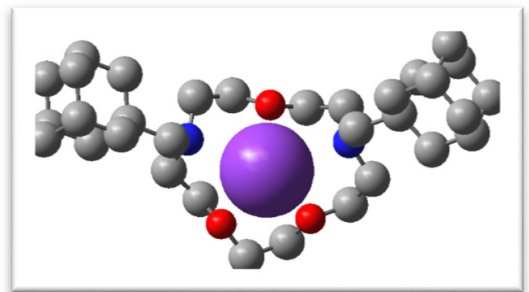

Compound $19+\mathrm{K}^{+}$

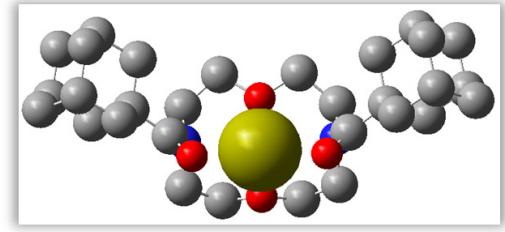

Compound $12+\mathrm{Ca}^{2+}$

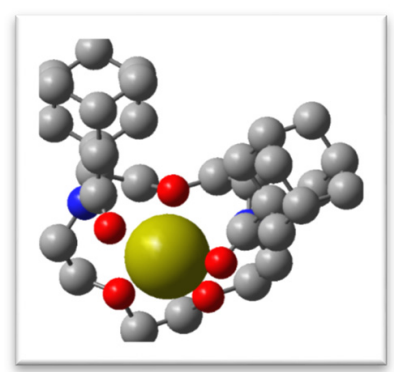

Comounpd $13+\mathrm{Ca}^{2+}$

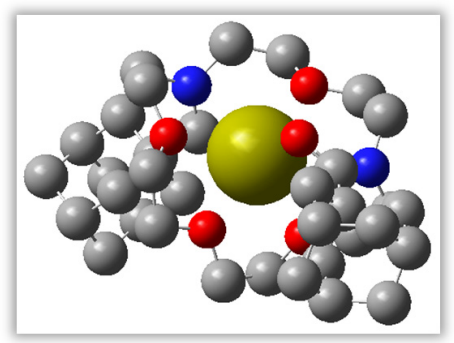

Compound $14+\mathrm{Ca}^{2+}$

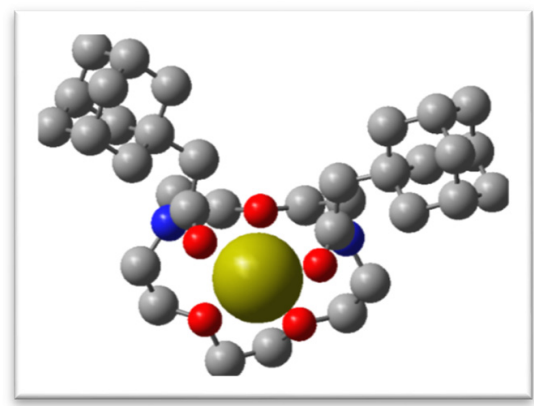

Compound $15+\mathrm{Ca}^{2+}$

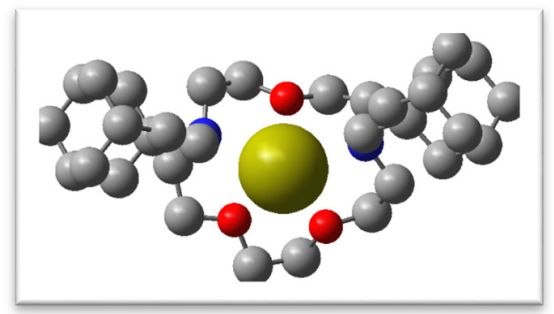

Compound $19+\mathrm{Ca}^{2+}$

Figure 4. DFT-optimized geometric structures of $\mathrm{Na}^{+}, \mathrm{K}^{+}$, and $\mathrm{Ca}^{2+}$ complexes with $\mathbf{1 2 - 1 5}$, and 19, ligands. Hydrogen atoms are not shown. 
DFT analysis of these structures demonstrated that the complexes of all three cations with diaza-12-crown-4 ether 12 and diaza-15-crown-5 ether 15, as well as of $\mathrm{Ca}^{2+}$ with diaza15-crown-5 ether 13, were characterized by a syn-arrangement of the carbonyl groups, while complexes of $\mathrm{Na}^{+}$and $\mathrm{K}^{+}$with ligand 13 had anti-oriented carbonyl groups. In complexes of diaza-18-crown-6 ether 14, the ligand had a trans-arrangement of the adamantyl-containing substituents, with the two carbonyl oxygen atoms attached to a cation from opposite sides of the median plane formed by the four in-cycle oxygen atoms (Figure 4). Such a mode of chelation becomes possible because of the large size of the macrocycle in diaza-18-crown-6 ether 14. The central cations were approximately "uniformly" surrounded by all oxygen atoms of ligands 13, 14, and diaza-15-crown-5 ether 19 (including the carbonyl oxygen atoms of 13 and 14), and the metal-oxygen internuclear distances varied within rather narrow ranges (Table 4 ). The same is true for the $\mathrm{Ca}^{2+}$ complex with diaza-12-crown- 4 ether 12. In complexes with diaza-15-crown-5 ether 15, four out of five oxygen atoms were relatively equidistant from a central cation, while either oxygen in the shorter segment connecting nitrogen atoms of the macrocycle was at a noticeably greater distance from a cation, especially in the case of alkali metal complexes (Table 4). Additionally, one of the macrocycle oxygen atoms in the $\mathrm{Na}^{+}$and $\mathrm{K}^{+}$complexes with ligand $\mathbf{1 2}$ was located 4.434 and $4.916 \AA$ apart from the central cation, respectively. Nitrogen atoms were involved only in the complexation of ligand 19 with the cations. The metal-nitrogen distances in complexes with this diaza-crown ether were much shorter than those in the coordination compounds of the corresponding cations with ligands 12-14, and 19, which also contain amide functions. The positions of ions surrounded by heteroatoms within the complexes were fairly stable, and our attempts to displace ions from the positions within $1 \AA$ led again to the structures shown in Figure 4 after further DFT optimization.

Table 4. Characteristics of $\mathrm{Na}^{+}, \mathrm{K}^{+}$, and $\mathrm{Ca}^{2+}$ complexes with diaza-crown ethers calculated by DFT method.

\begin{tabular}{|c|c|c|c|c|c|}
\hline Ligand & Cation $\left(\mathbf{M}^{\mathrm{n}+}\right)$ & NBO Charge at the Cation & $\begin{array}{c}\text { Metal-Oxygen } \\
\text { Distances, } \AA\end{array}$ & $\begin{array}{l}\text { Metal-Nitrogen } \\
\text { Distances, } \AA\end{array}$ & $\Delta \mathrm{U}, \mathrm{kcal} / \mathrm{mol}$ \\
\hline \multirow{3}{*}{12} & $\mathrm{Na}^{+}$ & 0.963 & $2.192 \ldots 4.434$ & 3.582 & -71.06 \\
\hline & $\mathrm{K}^{+}$ & 0.979 & $2.576 \ldots 4.916$ & 4.008 & -50.65 \\
\hline & $\mathrm{Ca}^{2+}$ & 1.814 & $2.302 \ldots 2.444$ & 2.673 & -216.65 \\
\hline \multirow{3}{*}{13} & $\mathrm{Na}^{+}$ & 0.899 & $2.332 \ldots 2.622$ & $2.930,3.030$ & -75.26 \\
\hline & $\mathrm{K}^{+}$ & 0.919 & $2.733 \ldots 2.938$ & $3.189,3.130$ & -55.84 \\
\hline & $\mathrm{Ca}^{2+}$ & 1.813 & $2.295 \ldots 2.490$ & $3.092,2.618$ & -239.26 \\
\hline \multirow{3}{*}{14} & $\mathrm{Na}^{+}$ & 0.886 & $2.316 \ldots 2.621$ & $3.146,3.267$ & -81.89 \\
\hline & $\mathrm{K}^{+}$ & 0.924 & $2.733 \ldots 3.007$ & $3.267,3.690$ & -59.46 \\
\hline & $\mathrm{Ca}^{2+}$ & 1.794 & $2.327 \ldots 2.444$ & $2.993,3.055$ & -257.27 \\
\hline \multirow{3}{*}{15} & $\mathrm{Na}^{+}$ & 0.951 & $4.145 *, 2.257 \ldots 2.507$ & $3.581,3.624$ & -79.30 \\
\hline & $\mathrm{K}^{+}$ & 0.967 & $4.499 *, 2.636 \ldots 2.980$ & $3.933,3.997$ & -60.10 \\
\hline & $\mathrm{Ca}^{2+}$ & 1.818 & $2.674 *, 2.279 \ldots 2.385$ & $3.090,2.837$ & -234.04 \\
\hline \multirow{3}{*}{19} & $\mathrm{Na}^{+}$ & 0.900 & $2.334 \ldots 2.373$ & $2.514,2.516$ & -81.01 \\
\hline & $\mathrm{K}^{+}$ & 0.944 & $2.709 \ldots 2.749$ & $2.882,2.885$ & -59.44 \\
\hline & $\mathrm{Ca}^{2+}$ & 1.790 & $2.316 \ldots 2.382$ & $2.482,2.480$ & -240.81 \\
\hline
\end{tabular}

* Distance from the central ion to the oxygen atom in the $\left(\mathrm{CH}_{2}\right)_{2} \mathrm{O}\left(\mathrm{CH}_{2}\right)_{2}$ segment connecting nitrogen atoms of the macrocycle.

The charges on alkali metal ions bound with the investigated ligands were calculated in the approximation of natural bond orbitals. These charges were about 0.1 e lower than the formal charges of the cations. For the doubly charged $\mathrm{Ca}^{2+}$, this decrease was $0.18 \ldots 0.21$ e (Table 4). The exceptions were when $\mathrm{Na}^{+}$and $\mathrm{K}^{+}$ions were bound with diaza-crown ethers 12 and 15, where the charges on the cations in these complexes were lower than formal values by only $0.021 . .0 .049$ e. The low degree of electron transfer from the ligand to cation in these cases is due to the remoteness of one of the oxygen atoms from the central 
ion (Table 4) and to the relatively high radius of $\mathrm{K}^{+}$. In addition, due to its large size, $\mathrm{K}^{+}$does not completely fit inside the cavity of compound 19 and is positioned above the median plane of the macrocycle, unlike the $\mathrm{Na}^{+}$ion (Figure 4). Therefore, the decrease in the formal charge of $\mathrm{K}^{+}$in the complex with diaza-crown ether $\mathbf{1 9}$ is also small and equal to $0.056 \mathrm{e}$.

We calculated the binding energy $\Delta \mathrm{U}$ for the complexation of $\mathrm{Na}^{+}, \mathrm{K}^{+}$, and $\mathrm{Ca}^{2+}$ ions with diaza-crown ethers according to the scheme:

$$
\mathrm{M}^{\mathrm{n}+}+\text { ligand } \rightarrow \mathrm{M}^{\mathrm{n}+} \cdot \text { ligand, } \Delta \mathrm{U}
$$

As shown in Table 4 , the $\Delta \mathrm{U}$ values for the formation of $\mathrm{Ca}^{2+}$ complexes with ligands 12-15, and 19 were significantly higher in absolute values than the binding energies for $\mathrm{Na}^{+}$and $\mathrm{K}^{+}$. These results indicate a pronounced selectivity of the macrocyclic compounds for coordination with $\mathrm{Ca}^{2+}$. In contrast, aza-crown ethers containing fused phenazine fragments were reported to bind alkali metal ions somewhat better [43]. Thus, DFT calculations in gas phase for phenazine-containing ligands led to absolute values of $\Delta U$ in the range of $96.6-104.9 \mathrm{kcal} / \mathrm{mol}$ upon interaction with $\mathrm{Na}^{+}$and $\mathrm{K}^{+}$, while the binding energy for $\mathrm{Ca}^{2+}$ did not exceed 79.0-88.9 $\mathrm{kcal} / \mathrm{mol}$ [43]. In terms of $\Delta \mathrm{U}$, the coordination compounds of $\mathrm{Ca}^{2+}$ with the ligands reported here are among the most stable complexes of doubly charged cations with crown and aza-crown ethers [43,44]. The DFT results do not include solvation/desolvation effects on complex formation, which are very difficult to account for in calculations of charged species, especially for individual metal ions. Thus, the $\Delta \mathrm{U}$ values obtained here refer to hypothetical gas phase processes, which is analogous to other reports [43-46].

The good geometric correspondence of $\mathrm{Ca}^{2+}$ to the cavity formed by the five oxygen atoms of ligands 12-15 (Figure 4, Table 4) indicates $\mathrm{Ca}^{2+}$ binds more effectively than alkali metal ions. This may be one of the reasons for the $\mathrm{Ca}^{2+}$-selective properties of these compounds in contrast to "classical" crown ethers like 18-crown-6 [7]. Complexation with aza- and diaza-crown ethers may help to explain the ionophore mechanism of $\mathrm{Ca}^{2+}$ transport. The bound ions are "hidden" inside the complex together with the polar nitrogen and oxygen atoms. "Outside" of these adducts are only non-polar and lipophilic adamantane substituents, as well as hydrocarbon groups of the macrocycles. This is illustrated in Figure 5, where shades of color indicate electrostatic potential (ESP) values mapped onto the electron density isosurfaces of the bound cations. Small dark-blue spots in the center of each upper panel correspond to highly positively charged areas occupied by $\mathrm{Ca}^{2+}$, which are surrounded by large and significantly less positively charged (lightblue) outer surfaces of macrocyclic ligands with the chosen ESP boundaries of the palette between -0.35 (highly negative, red) to 0.35 (highly positive, dark-blue). Assigning the ESP palette between 0.12 (low positive, red) to 0.2 (medium positive, dark blue) allows one to observe substantial differences in charge distributions in $\mathrm{Ca}^{2+}$ complexes with the carbonyl-containing compound $\mathbf{1 5}$ and the aza-crown ether 19 containing tertiary amine moieties. Indeed, the complex with 19 has smaller red and yellow areas of low positive ESP, which are prone to hydrophobic interactions, than the complex with aza-crown ether $\mathbf{1 5}$ These differences may be one of the reasons for lower biological activity of aza-crown ether 19 in spite of its higher binding energy with $\mathrm{Ca}^{2+}$ and are in agreement with ionophore mechanism of biological action when the ability of a ligand to transfer cations through cell membranes is more important than strong binding with the cation. 

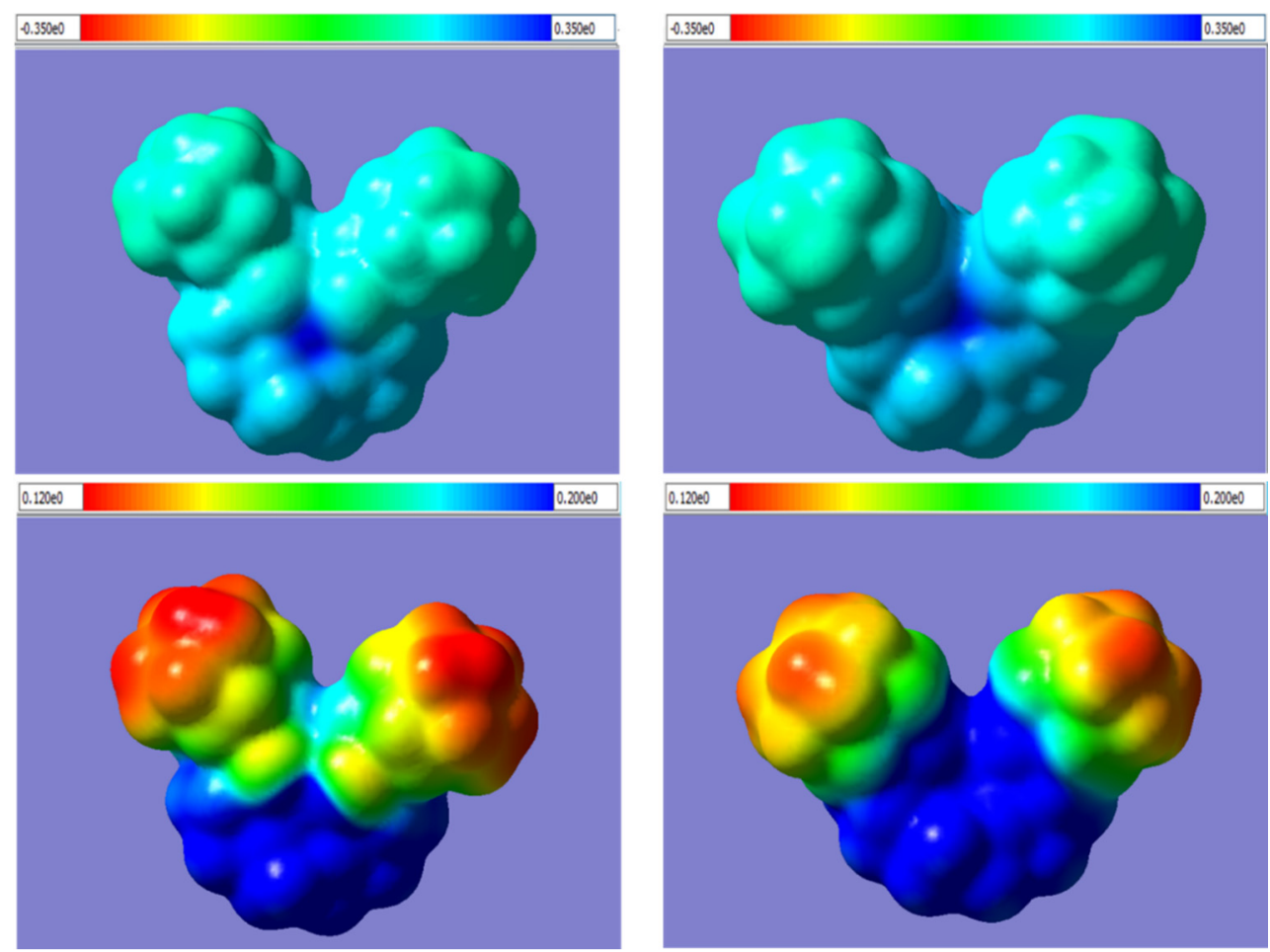

Figure 5. Electrostatic potential (ESP) mapped onto the isosurfaces of electron density (isovalue 0.0004) for Ca ${ }^{2+}$ complexes with diaza-crown ethers 15 (left panels) and 19 (right panels) calculated by the DFT method. Color shades correspond to different values of ESP, which vary from -0.35 (red) to 0.35 (blue) (upper panels) and from 0.12 and lower (red) to 0.20 and higher (dark-blue) (bottom panels).

We also performed quantitative structure-activity relationship (QSAR) analysis of the series of compounds 5-21 based on absorption, distribution, metabolism and excretion (ADME) parameters generated using the SwissADME web server [47]. The chosen subset contains all active compounds and several inactive aza-crown ethers. QSAR analysis of biologically-active crown- and aza-crown ethers was also previously performed by Supek et al. [16], where importance of the ligand physico-chemical properties was established. Here, we initially considered the following variables for the analysis: molecular weight (MW), number of heavy atoms $\left(\mathrm{N}_{\text {ha }}\right)$, number of aromatic heavy atoms $\left(\mathrm{N}_{\mathrm{ar}}\right)$, fraction of $\mathrm{sp}^{3}$-carbons among all carbon atoms $\left(\mathrm{C}_{\mathrm{sp} 3}\right)$, number of rotatable bonds $\left(\mathrm{N}_{\mathrm{rot}}\right)$, number of $\mathrm{H}$-bond acceptors $\left(\mathrm{N}_{\mathrm{HBA}}\right)$, molar refractivity (MR), topological polar surface area (tPSA), measure of lipophilicity iLog P [48], number of carbonyl groups $\left(\mathrm{N}_{\mathrm{C}=\mathrm{O}}\right)$, and number of adamantyl groups $\left(\mathrm{N}_{\mathrm{Ad}}\right)$. However, we found that MR, MW, and $\mathrm{N}_{\text {ha }}$ were tightly correlated with each other for our compounds, with pairwise correlation coefficients (r) within $0.99 \ldots 1.00$. Hence, from these three characteristics, we chose only MR as a representative independent variable for inclusion in the analysis. In addition, $\mathrm{N}_{\mathrm{ar}}$ and $\mathrm{C}_{\mathrm{sp} 3}$ were correlated $(\mathrm{r}=-0.96)$. We constructed two QSAR models with inclusion of one of these two variables along with $\mathrm{N}_{\mathrm{rot}}, \mathrm{N}_{\mathrm{HBA}}, \mathrm{MR}, \mathrm{N}_{\mathrm{C}=\mathrm{O}}, \mathrm{N}_{\mathrm{ad}}$, tPSA, and iLog P (Table 5). To account for inactive compounds, we used the reciprocal values of $\mathrm{EC}_{50}$ in human neutrophils as a measure of biological activity (elevation of neutrophil $\left[\mathrm{Ca}^{2+}\right]_{\mathrm{i}}$ ), where inactive compounds were assigned a value of zero. This measure $\left(1 /\left[\mathrm{EC}_{50}\right]\right)$ was used as a dependent variable. 
Table 5. The biological activities of aza-crown ethers and variables used in the regression analysis.

\begin{tabular}{|c|c|c|c|c|c|c|c|c|c|c|c|c|c|}
\hline Compd. & MW & $\mathbf{N}_{\text {ha }}$ & $\mathbf{N}_{\mathrm{ar}}$ & $\operatorname{Csp}^{3}$ & $\mathrm{~N}_{\text {rot }}$ & $\mathrm{N}_{\text {HBA }}$ & $\mathbf{N}_{\text {HBD }}$ & MR & tPSA & iLog P & $\mathrm{N}_{\mathrm{C}=\mathrm{O}}$ & $\mathbf{N}_{\text {Ad }}$ & $1 /\left[E_{50}\right]$ \\
\hline 5 & 337.45 & 24 & 0 & 0.95 & 2 & 4 & 0 & 95 & 48.00 & 3.29 & 1 & 1 & 0 \\
\hline 6 & 381.51 & 25 & 0 & 0.95 & 2 & 5 & 0 & 105.7 & 57.23 & 3.65 & 1 & 1 & 0 \\
\hline 7 & 425.56 & 30 & 0 & 0.96 & 2 & 6 & 0 & 116.39 & 66.46 & 3.94 & 1 & 1 & 0 \\
\hline 8 & 395.53 & 28 & 0 & 0.95 & 3 & 5 & 0 & 110.5 & 57.23 & 3.81 & 1 & 1 & 0.04464 \\
\hline 9 & 439.59 & 31 & 0 & 0.96 & 3 & 6 & 0 & 121.2 & 66.46 & 3.83 & 1 & 1 & 0 \\
\hline 10 & 429.55 & 31 & 6 & 0.72 & 2 & 5 & 0 & 121.61 & 57.23 & 3.69 & 1 & 1 & 0.10309 \\
\hline 11 & 443.58 & 32 & 6 & 0.73 & 3 & 5 & 0 & 126.42 & 57.23 & 4.02 & 1 & 1 & 0.06410 \\
\hline 12 & 498.7 & 36 & 0 & 0.93 & 4 & 4 & 0 & 147.2 & 59.08 & 4.36 & 2 & 2 & 0.04201 \\
\hline 13 & 542.75 & 39 & 0 & 0.94 & 4 & 5 & 0 & 157.9 & 68.31 & 4.59 & 2 & 2 & 0.14493 \\
\hline 14 & 586.8 & 42 & 0 & 0.94 & 4 & 6 & 0 & 168.6 & 77.54 & 4.73 & 2 & 2 & 0.10526 \\
\hline 15 & 570.8 & 41 & 0 & 0.94 & 6 & 5 & 0 & 167.51 & 68.31 & 5.28 & 2 & 2 & 0.21277 \\
\hline 16 & 586.8 & 42 & 0 & 0.94 & 4 & 6 & 0 & 168.6 & 77.54 & 5.31 & 2 & 2 & 0.06369 \\
\hline 17 & 614.86 & 44 & 0 & 0.94 & 6 & 6 & 0 & 178.21 & 77.54 & 4.94 & 2 & 2 & 0.06289 \\
\hline 18 & 367.52 & 26 & 0 & 1 & 2 & 5 & 0 & 105.5 & 40.16 & 3.72 & 0 & 1 & 0 \\
\hline 19 & 514.78 & 37 & 0 & 1 & 4 & 5 & 0 & 157.5 & 34.17 & 4.72 & 0 & 2 & 0 \\
\hline 20 & 558.84 & 40 & 0 & 1 & 4 & 6 & 0 & 168.2 & 43.40 & 5.74 & 0 & 2 & 0 \\
\hline 21 & 586.89 & 42 & 0 & 1 & 6 & 6 & 0 & 177.81 & 43.40 & 6.44 & 0 & 2 & 0.08850 \\
\hline 22 & 444.61 & 31 & 0 & 0.91 & 12 & 7 & 2 & 128.45 & 120.35 & 3.81 & 2 & 0 & 0 \\
\hline 23 & 400.56 & 28 & 0 & 0.90 & 12 & 6 & 2 & 117.75 & 111.12 & 3.19 & 2 & 0 & 0 \\
\hline 24 & 528.64 & 38 & 12 & 0.50 & 6 & 8 & 2 & 150.42 & 129.58 & 2.99 & 2 & 0 & 0 \\
\hline 25 & 376.49 & 26 & 0 & 0.94 & 6 & 7 & 1 & 101.67 & 92.48 & 3.59 & 1 & 0 & 0 \\
\hline 26 & 332.44 & 23 & 0 & 0.94 & 6 & 6 & 1 & 90.97 & 83.25 & 2.95 & 1 & 0 & 0 \\
\hline 27 & 352.43 & 25 & 6 & 0.61 & 3 & 6 & 1 & 96.61 & 83.25 & 2.31 & 1 & 0 & 0 \\
\hline 28 & 378.42 & 26 & 0 & 0.88 & 4 & 10 & 2 & 98.42 & 118.00 & 2.07 & 2 & 0 & 0 \\
\hline
\end{tabular}

Abbreviations: MW, molecular weight $(\mathrm{g} / \mathrm{mol}) ; \mathrm{N}_{\mathrm{ha}}$, number of heavy atoms; $\mathrm{N}_{\mathrm{ar}}$, number of aromatic heavy atoms; Csp ${ }^{3}$, fraction of $\mathrm{sp}^{3}$-carbons among all carbon atoms; $\mathrm{N}_{\text {rot }}$, number of rotatable bonds; $\mathrm{N}_{\mathrm{HBA}}$, number of H-bond acceptors; MR, molar refractivity $\left(\mathrm{cm}^{3} / \mathrm{mol}\right)$; tPSA, topological polar surface area $\left(\AA^{2}\right)$; iLog $\mathrm{P}$, lipophilicity (consensus Log Po/w); $\mathrm{N}_{\mathrm{C}=\mathrm{O}}, \mathrm{number}$ of carbonyl groups; $\mathrm{N}_{\mathrm{Ad}}$, number of adamantyl groups.

Forward stepwise regression analyses with the data presented in Table 5 and alternate inclusion of $\mathrm{N}_{\mathrm{ar}}$ or $\mathrm{C}_{\mathrm{sp} 3}$ gave the best regression Equations (1) and (2) with four variables:

$1 / \mathrm{EC}_{50}=-0.058+0.230 \cdot \mathrm{N}_{\mathrm{ar}}-0.574 \mathrm{tPSA}+0.471 \mathrm{iLog} \mathrm{P}+0.797 \cdot \mathrm{N}_{\mathrm{C}=\mathrm{O}} ; \mathrm{n}=24, \mathrm{R}=0.778, \mathrm{~s}=0.040$

$1 / \mathrm{EC}_{50}=0.056-0.281 \cdot \mathrm{Csp}^{3}-0.588 \mathrm{tPSA}+0.518 \mathrm{iLog} \mathrm{P}+0.763 \cdot \mathrm{N}_{\mathrm{C}=\mathrm{O}} ; \mathrm{n}=24, \mathrm{R}=0.784, \mathrm{~s}=0.039$

The plot of calculated vs. experimental biological activities for the best QSAR model (2) is shown in Figure 6. 


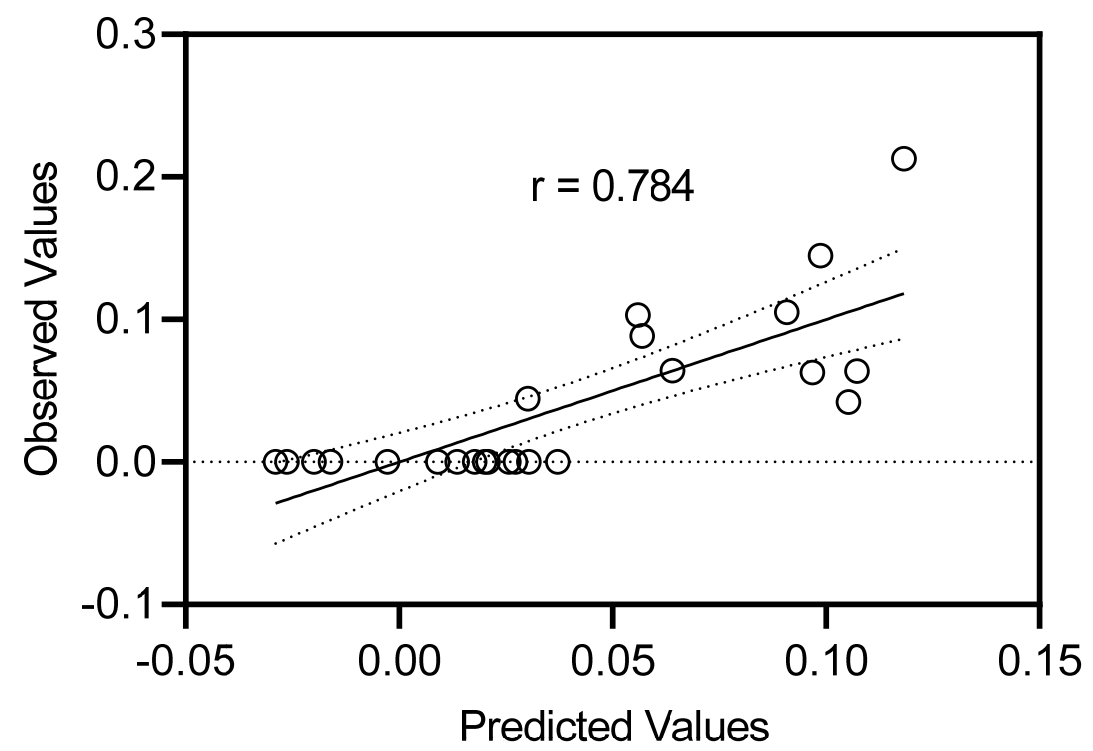

Figure 6. Plot of calculated vs. experimental biological activities $\left(1 / \mathrm{EC}_{50}\right)$ obtained with regression Equation (2).

The regressions were of comparable quality with multiple correlation coefficients of $\sim 0.784$. Both models include iLog $\mathrm{P}$ and $\mathrm{N}_{\mathrm{C}=\mathrm{O}}$ with positive coefficients and tPSA with a negative coefficient, i.e., the presence of carbonyl groups and an increase of hydrophobicity favor biological activity. According to Equations (1) and (2), the presence of benzene rings or a corresponding decrease of $\mathrm{C}_{\mathrm{sp} 3}$ were also favorable for biological activity. Aromatic rings are lipophilic moieties that enhance shielding of the positively charged central ions from the hydrophobic environment during cation transportation. The DFT-optimized structures of the complexes showed that the carbonyl oxygen atoms of the aza-crown ethers participated in cation binding (Figure 4). Thus, they can play an important role in $\mathrm{Ca}^{2+}$ transfer through cell membranes. It should be noted that the previously reported U-shaped relationship between biological activity and lipophilicity [16] was not observed for the series of compounds shown here.

Our results indicate that ADME characteristics of the ligands largely define their $\mathrm{Ca}^{2+}$ ionophore properties. According to the DFT results, $\mathrm{Ca}^{2+}$ can be more effectively bound by the diaza-crown ethers than $\mathrm{Na}^{+}$or $\mathrm{K}^{+}$. Noticeably, the binding energies $\Delta \mathrm{U}$ of the $\mathrm{Ca}^{2+}$ complexes (Table 3) did not correlate with the observed biological activities of diaza-crown ethers investigated by the DFT method. Clearly, there is a need not only for strong binding of the cation, but also for its relatively easy ion transport through membranes and release at the final stage of transport for good ionophore properties of the macrocyclic ligands, as discussed above (Figure 5).

\section{Materials and Methods}

\subsection{General Information}

The structures of the synthesized compounds were determined by ${ }^{1} \mathrm{H}$ and ${ }^{13} \mathrm{C} N \mathrm{NMR}$ on a Bruker AVANCE DRX 500 spectrometer operating at $499.87 \mathrm{MHz}\left({ }^{1} \mathrm{H}\right)$ and $125.69 \mathrm{MHz}$ $\left({ }^{13} \mathrm{C}\right.$ ) for $\sim 10 \%$ solutions in dimethyl sulfoxide (DMSO)- $\mathrm{d}_{6}$ and $\mathrm{CDCl}_{3}$ with tetramethylsilane (TMS) as an internal standard. Mass spectra were obtained by the fast atom bombardment (FAB) method on a VG 70-70EQ mass spectrometer using an $8 \mathrm{kV}$ Xe atomic beam and $m$ nitrobenzyl alcohol as a matrix. Melting points were measured in open capillaries and are not corrected. The reactions were controlled by TLC on Kieselgel 60 F254 plates (Merck); purification was carried out by crystallization or column chromatography on silica gel (Kieselgel 60 $0.063-0.100 \mathrm{~mm}$, Merk). Purity of the compounds was determined by high-performance liquid chromatograph (HPLC) using a Shimadzu chromatography system (controller of the CBM-20A system; vacuum degasser DGU-20 A5; high-pressure pump LC-20AD UFLC 
equipped with a 4-channel low-pressure gradient block; column thermostat CTO-20A; diode matrix detector SPD-M20A) equipped with an Acclaim Polar Advantage II $3 \mu \mathrm{m}$ column $(4.6 \mathrm{~mm} \times 150 \mathrm{~mm})$ with a Guard cartridge and a manual injector with a $10 \mu \mathrm{L}$ loop. Mobile phase: acetonitrile (30\%) and $0.1 \%$ solution of trifluoroacetic acid in deionized water (70\%). Mobile phase flow rate: $1.0 \mathrm{~mL} / \mathrm{min}$. The injection volume was $10 \mu \mathrm{L}$. Thermostat temperature: $20^{\circ} \mathrm{C}$. UV scanning range: $190-400 \mathrm{~nm}$. The purity of the synthesized compounds was at least $98.5 \%$ according to HPLC.

The starting aza-crown ethers (aza-15-crown-5, aza-18-crown-6, benzoaza-15-crown5, 4,10-diaza-12-crown-4, 4,10-diaza-15-crown-5, 4,10-diaza-18-crown-6) [49-51], 6-(Bocamino)hexanoic and 4-(Boc-aminomethyl)benzoic acids, adamantane-1-carbonyl chloride, 2-(adamantan-1-yl)acetyl chloride, and diborane [52,53] were obtained by standard methods. Their spectral characteristics and physical constants were identical to those given in the literature.

\subsection{Chemistry}

3.2.1. General Procedure for Synthesis Compounds 1-4, 10, and 11

To a solution of $10 \mathrm{mmol}$ of amine or the corresponding monoaza-crown ether in $10 \mathrm{~mL}$ of anhydrous chloroform, triethylamine $1.53 \mathrm{~mL}(11 \mathrm{mmol})$ was added. The reaction mixture was cooled to $0{ }^{\circ} \mathrm{C}$, and a solution of $10 \mathrm{mmol}$ adamantane-1-carbonyl chloride or 2-(adamantan-1-yl)acetyl chloride in $10 \mathrm{~mL}$ of anhydrous chloroform was added dropwise for $5 \mathrm{~min}$ with vigorous stirring. The reaction mixture was stirred for $2 \mathrm{~h}$, and $40 \mathrm{~mL}$ of chloroform was added. The combined organic phase was washed successively with water $(2 \times 10 \mathrm{~mL}), 1 \mathrm{~N}$ hydrochloric acid $(1 \times 10 \mathrm{~mL}), \mathrm{H}_{2} \mathrm{O}(1 \times 1 \mathrm{~mL}), 10 \% \mathrm{Na}_{2} \mathrm{CO}_{3}$ solution $(2 \times 10 \mathrm{~mL})$, and $\mathrm{H}_{2} \mathrm{O}(1 \times 10 \mathrm{~mL})$. The organic phase was dried with anhydrous $\mathrm{Na}_{2} \mathrm{SO}_{4}$, and the solvent was removed on a rotary evaporator to dryness. The products were purified by recrystallization from hexane.

Methyl 6-(adamantane-1-carboxamido)hexanoate (1). Yield 85\%. Colorless crystals. MP 52-56 ${ }^{\circ} \mathrm{C} . \mathrm{NMR}^{1} \mathrm{H}\left(\mathrm{CDCl}_{3}\right) \delta_{\mathrm{H}}, 1.28-1.34\left(\mathrm{~m}, 2 \mathrm{H}, \mathrm{CH}_{2}\right), 1.45-1.51\left(\mathrm{~m}, 2 \mathrm{H}, \mathrm{CH}_{2}\right), 1.59-1.63$ (m, 2H, $\mathrm{CH}_{2}$ ), 1.65-1.73 (m, 6H, Ad), 1.82 (br.s, 6H, Ad), 2.01 (br.s, 3H, Ad), 2.28-2.31 (m,

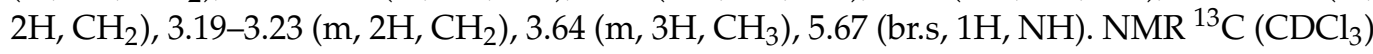
$\delta_{\mathrm{C}}, 24.46\left(1 \mathrm{C}, \mathrm{CH}_{2}\right), 26.29\left(1 \mathrm{C}, \mathrm{CH}_{2}\right), 28.14(3 \mathrm{C}, \mathrm{Ad}), 29.26\left(1 \mathrm{C}, \mathrm{CH}_{2}\right), 33.85\left(1 \mathrm{C}, \mathrm{CH}_{2}\right), 36.52$ (3C, Ad), $38.97\left(1 \mathrm{C}, \mathrm{CH}_{2}\right), 39.27$ (3C, Ad), 40.55 (1C, Ad), $51.47\left(1 \mathrm{C}, \mathrm{CH}_{3}\right), 174.04(1 \mathrm{C}, \mathrm{COO})$, 177.97(1C, CON). MS, m/z: $292(\mathrm{M}+\mathrm{H})^{+}$.

N-(1-adamantyl)adamantane-1-carboxamide (2). Yield 87\%. Colorless crystals. MP 255$257^{\circ} \mathrm{C} . \mathrm{NMR}^{1} \mathrm{H}\left(\mathrm{CDCl}_{3}\right) \delta_{\mathrm{H}}, 1.67-1.74$ (m, 12H, Ad), 1.80 (br.s, 6H, Ad), 1.98 (br.s, 6H, Ad), 2.02 (br.s, 3H, Ad), 2.06 (br.s, 3H, Ad), 5.22 (br.s, 1H, NH). NMR ${ }^{13} \mathrm{C}\left(\mathrm{CDCl}_{3}\right) \delta_{\mathrm{C}}, 28.26(3 \mathrm{C}$, Ad), 29.50 (3C, Ad), 36.44 (3C, Ad), 36.58 (3C, Ad), 39.42 (3C, Ad), 40.88 (1C, AdCO), 41.66 (3C, Ad), $51.18(1 \mathrm{C}, \mathrm{AdNH}), 177.23(1 \mathrm{C}, \mathrm{CON}) . \mathrm{MS}, \mathrm{m} / z: 314(\mathrm{M}+\mathrm{H})^{+}$.

N,2-di(1-adamantyl)acetamide (3). Yield 93\%. Colorless crystals. MP 242-244 ${ }^{\circ} \mathrm{C}$. NMR ${ }^{1} \mathrm{H}\left(\mathrm{CDCl}_{3}\right) \delta_{\mathrm{H}}, 1.46$ (br.s, 6H, Ad), 1.61-1.64 (m, 3H, Ad), 1.70-1.79 (m, 9H, Ad), 1.87 (br.s, 6H, Ad), 1.97 (br.s, 3H, Ad), 2.04 (br.s, 3H, Ad), 2.93-2.95 (d, J 6.2 Hz, 2H, Ad), 5.63 (br.s, $1 \mathrm{H}, \mathrm{NH}) . \mathrm{NMR}{ }^{13} \mathrm{C}\left(\mathrm{CDCl}_{3}\right) \delta_{\mathrm{C}}, 28.22(3 \mathrm{C}, \mathrm{Ad}), 28.24(3 \mathrm{C}, \mathrm{Ad}), 33.82\left(1 \mathrm{C}, \mathrm{CH}_{2}\right), 36.58(3 \mathrm{C}$, Ad), 36.99 (3C, Ad), 39.52 (3C, Ad), 40.32 (3C, Ad), 40.88 (1C, Ad), 50.42 (1C, AdNH), 177.87 (1C, CON). MS, $m / z: 328(\mathrm{M}+\mathrm{H})^{+}$.

N-cyclohexyladamantane-1-carboxamide (4). Yield 96\%. Colorless crystals. MP $174-176{ }^{\circ} \mathrm{C}$. $\mathrm{NMR}{ }^{1} \mathrm{H}\left(\mathrm{CDCl}_{3}\right) \delta_{\mathrm{H}}, 1.06-1.20\left(\mathrm{~m}, 3 \mathrm{H}, \mathrm{CH}_{2}\right), 1.33-1.40\left(\mathrm{~m}, 2 \mathrm{H}, \mathrm{CH}_{2}\right), 1.59-1.63\left(\mathrm{~m}, 1 \mathrm{H}, \mathrm{CH}_{2}\right)$, 1.68-1.75 (m, 6H, Ad, 2H, CH 2$), 1.83$ (br.s, 6H, Ad), 1.86-1.88 (m, 2H, $\mathrm{CH}_{2}$ ), 2.03 (br.s, 3H, Ad), 3.72-3.78 (m, 1H, CH), 5.41 (br.s, $1 \mathrm{H}, \mathrm{NH}) . \mathrm{NMR}{ }^{13} \mathrm{C}\left(\mathrm{CDCl}_{3}\right) \delta_{\mathrm{C}}, 24.86\left(2 \mathrm{C}, \mathrm{CH}_{2}\right), 25.62(1 \mathrm{C}$, $\left.\mathrm{CH}_{2}\right), 28.19$ (3C, Ad), 33.19 (2C, $\left.\mathrm{CH}_{2}\right), 36.57$ (3C, Ad), 39.30 (3C, Ad), 40.43 (1C, Ad), 47.56 (1C, $\left.\mathrm{CH}_{2}\right), 176.96(1 \mathrm{C}, \mathrm{CON}) . \mathrm{MS}, m / z: 262(\mathrm{M}+\mathrm{H})^{+}$.

N-[1-Oxo-1-(1-adamantyl)methyl]benzoaza-15-crown-5 (10). Yield 89\%. Colorless crystals. MP 111-113 ${ }^{\circ} \mathrm{C} . \mathrm{NMR}^{1} \mathrm{H}\left(\mathrm{CDCl}_{3}\right) \delta_{\mathrm{H}}, 1.72$ (br.s, 6H, Ad), 2.00 (br.s, 6H, Ad), 2.03 (br.s, 3H, Ad), 3.67 (br.s, 4H, $\mathrm{CH}_{2} \mathrm{~N}$ ), 3.87 (br.s, 8H, CH $2 \mathrm{O}$ ), 4.11 (br.s, 4H, $\mathrm{CH}_{2} \mathrm{O}$ ), 6.90 (d, J $12.0 \mathrm{~Hz}$, $4 \mathrm{H}, \mathrm{Ar}) . \mathrm{NMR}{ }^{13} \mathrm{C}\left(\mathrm{CDCl}_{3}\right) \delta_{\mathrm{C}}, 28.55(3 \mathrm{C}, \mathrm{Ad}), 36.62(3 \mathrm{C}, \mathrm{Ad}), 39.11(3 \mathrm{C}, \mathrm{Ad}), 42.16(1 \mathrm{C}$, 
Ad), $50.68\left(2 \mathrm{C}, \mathrm{CH}_{2} \mathrm{~N}\right), 69.38\left(2 \mathrm{C}, \mathrm{CH}_{2} \mathrm{O}\right), 69.86\left(2 \mathrm{C}, \mathrm{CH}_{2} \mathrm{O}\right), 71.07\left(2 \mathrm{C}, \mathrm{CH}_{2} \mathrm{O}\right), 113.30(2 \mathrm{C}$, Ar), $121.30(2 \mathrm{C}, \mathrm{Ar}), 148.80(2 \mathrm{C}, \mathrm{Ar}), 177.19(1 \mathrm{C}, \mathrm{CON}) . \mathrm{MS}, \mathrm{m} / z: 430(\mathrm{M}+\mathrm{H})^{+}$.

N-[2-(1-adamantyl)acetyl]benzoaza-15-crown-5 (11). Yield 90\%. Colorless crystals. MP 141-142 ${ }^{\circ} \mathrm{C}$. NMR ${ }^{1} \mathrm{H}\left(\mathrm{CDCl}_{3}\right) \delta_{\mathrm{H}}, 1.63-1.69(\mathrm{~m}, 12 \mathrm{H}, \mathrm{Ad}), 1.94$ (br.s, $\left.3 \mathrm{H}, \mathrm{Ad}\right), 2.14$ (br.s, $\left.2 \mathrm{H}, \mathrm{CH}_{2}\right), 3.58-3.64\left(\mathrm{~m}, 4 \mathrm{H}, \mathrm{CH}_{2} \mathrm{~N}\right), 3.72-3.74\left(\mathrm{~m}, 2 \mathrm{H}, \mathrm{CH}_{2} \mathrm{O}\right), 3.80-3.82\left(\mathrm{~m}, 2 \mathrm{H}, \mathrm{CH}_{2} \mathrm{O}\right)$, 3.93-3.98 (m, 4H, $\left.\mathrm{CH}_{2} \mathrm{O}\right), 4.10-4.14\left(\mathrm{~m}, 4 \mathrm{H}, \mathrm{CH}_{2} \mathrm{O}\right), 6.87-6.93(\mathrm{~m}, 4 \mathrm{H}, \mathrm{Ar}) .{ }^{13} \mathrm{C} \mathrm{NMR}\left(\mathrm{CDCl}_{3}\right)$ $\delta_{\mathrm{C}}, 28.74(3 \mathrm{C}, \mathrm{Ad}), 33.68(1 \mathrm{C}, \mathrm{Ad}), 36.87(3 \mathrm{C}, \mathrm{Ad}), 42.72$ (3C, Ad), 45.84 (1C, $\left.\mathrm{CH}_{2} \mathrm{Ad}\right), 49.41$ $\left(1 \mathrm{C}, \mathrm{CH}_{2} \mathrm{~N}\right), 51.10\left(1 \mathrm{C}, \mathrm{CH}_{2} \mathrm{~N}\right), 68.50\left(1 \mathrm{C}, \mathrm{CH}_{2} \mathrm{O}\right), 69.36\left(1 \mathrm{C}, \mathrm{CH}_{2} \mathrm{O}\right), 70.01\left(1 \mathrm{C}, \mathrm{CH}_{2} \mathrm{O}\right)$, $70.10\left(1 \mathrm{C}, \mathrm{CH}_{2} \mathrm{O}\right), 70.34\left(1 \mathrm{C}, \mathrm{CH}_{2} \mathrm{O}\right), 71.11\left(1 \mathrm{C}, \mathrm{CH}_{2} \mathrm{O}\right), 113.28(1 \mathrm{C}, \mathrm{Ar}), 113.33(1 \mathrm{C}, \mathrm{Ar})$, 121.28 (1C, Ar), 121.37 (1C, Ar), 148.72 (1C, Ar), 148.81 (1C, Ar), 171.85 (1C, CON). MS, $m / z$ : $444(\mathrm{M}+\mathrm{H})^{+}$.

$\mathrm{N}$-[1-Oxo-1-(1-adamantyl)methyl]aza-12-crown-4 (5), N-[1-oxo-1-(1-adamantyl)methyl] aza-15-crown-5 (6), N-[1-oxo-1-(1-adamantyl)methyl]aza-18-crown-6 (7), N-[2-(1-adamantyl) acetyl]aza-15-crown-5 (8), and $N$-[2-(1-adamantyl)acetyl]aza-18-crown-6 (9) were synthesized as described previously $[17,54,55]$.

\subsubsection{General Procedure for Synthesis Compounds 14 and 15}

To a solution of $10 \mathrm{~mol}$ of the corresponding diaza-crown ether in $15 \mathrm{~mL}$ of anhydrous chloroform, triethylamine $3.5 \mathrm{~mL}$ ( $25 \mathrm{mmol}$ ) was added. The reaction mixture was cooled to $0{ }^{\circ} \mathrm{C}$, and a solution of $21 \mathrm{mmol}$ adamantane-1-carbonyl chloride or 2-(adamantan-1-yl)acetyl chloride in $15 \mathrm{~mL}$ of anhydrous chloroform was added dropwise for $5 \mathrm{~min}$ with vigorous stirring. The reaction mixture was stirred for $2 \mathrm{~h}$, and $40 \mathrm{~mL}$ of chloroform was added. The combined organic phase was washed successively with $\mathrm{H}_{2} \mathrm{O}(2 \times 10 \mathrm{~mL}), 1 \mathrm{~N} \mathrm{HCl}$ $(1 \times 10 \mathrm{~mL})$, water $(1 \times 10 \mathrm{~mL}), 10 \% \mathrm{Na}_{2} \mathrm{CO}_{3}$ solution $(2 \times 10 \mathrm{~mL})$, and $\mathrm{H}_{2} \mathrm{O}(1 \times 10 \mathrm{~mL})$. The organic phase was dried with anhydrous $\mathrm{Na}_{2} \mathrm{SO}_{4}$, and the solvent was removed on a rotary evaporator to dryness. The products were purified by recrystallization from hexane.

N,N'-bis[1-oxo-1-(1-adamantyl)methyl]-4,10-diaza-18-crown-6 (14). Yield 97\%. Colorless crystals. MP 91-93 ${ }^{\circ} \mathrm{C}$. NMR ${ }^{1} \mathrm{H}\left(\mathrm{CDCl}_{3}\right) \delta_{\mathrm{H}}, 1.71$ (br.s, $\left.12 \mathrm{H}, \mathrm{Ad}\right), 1.98$ (br.s, $\left.12 \mathrm{H}, \mathrm{Ad}\right), 2.03$ (br.s, 6H, Ad), 3.60-3.68 (m, 24H, $\left.\mathrm{CH}_{2} \mathrm{O}\right)$. NMR ${ }^{13} \mathrm{C}\left(\mathrm{CDCl}_{3}\right) \delta_{\mathrm{C}}, 28.53(6 \mathrm{C}, \mathrm{Ad}), 36.61(6 \mathrm{C}$, $\mathrm{Ad}), 39.19(6 \mathrm{C}, \mathrm{Ad}), 42.09(2 \mathrm{C}, \mathrm{Ad}), 49.07\left(2 \mathrm{C}, \mathrm{CH}_{2} \mathrm{~N}\right), 49.52\left(2 \mathrm{C}, \mathrm{CH}_{2} \mathrm{~N}\right), 70.32\left(4 \mathrm{C}, \mathrm{CH}_{2} \mathrm{O}\right)$, $70.57\left(2 \mathrm{C}, \mathrm{CH}_{2} \mathrm{O}\right), 70.92\left(2 \mathrm{C}, \mathrm{CH}_{2} \mathrm{O}\right), 177.01(2 \mathrm{C}, \mathrm{CON}) . \mathrm{MS}, m / z: 531(\mathrm{M}+\mathrm{H})^{+}$.

N,N'-bis[2-(1-adamantyl)acetyl]-4,10-diaza-15-crown-5 (15). Yield 91\%. Colorless crystals. MP 72-76 ${ }^{\circ} \mathrm{C} . \mathrm{NMR}^{1} \mathrm{H}\left(\mathrm{CDCl}_{3}\right) \delta_{\mathrm{H}}, 1.63-1.70(\mathrm{~m}, 24 \mathrm{H}, \mathrm{Ad}), 1.95$ (br.s, 6H, Ad), 2.08-2.17 (m, 4H, CH $2 \mathrm{Ad}), 3.55-3.73\left(\mathrm{~m}, 20 \mathrm{H}, \mathrm{CH}_{2} \mathrm{O}\right)$. NMR ${ }^{13} \mathrm{C}\left(\mathrm{CDCl}_{3}\right) \delta_{\mathrm{C}}, 28.73(6 \mathrm{C}, \mathrm{Ad}), 33.67$ (2C, $\mathrm{Ad}), 36.85(6 \mathrm{C}, \mathrm{Ad}), 42.77(6 \mathrm{C}, \mathrm{Ad}), 45.95\left(2 \mathrm{C}, \mathrm{CH}_{2} \mathrm{Ad}\right), 48.59\left(2 \mathrm{C}, \mathrm{CH}_{2} \mathrm{~N}\right), 50.30(2 \mathrm{C}$, $\left.\mathrm{CH}_{2} \mathrm{~N}\right), 69.04\left(2 \mathrm{C}, \mathrm{CH}_{2} \mathrm{O}\right), 70.23\left(1 \mathrm{C}, \mathrm{CH}_{2} \mathrm{O}\right), 70.55\left(1 \mathrm{C}, \mathrm{CH}_{2} \mathrm{O}\right), 70.74\left(1 \mathrm{C}, \mathrm{CH}_{2} \mathrm{O}\right), 71.04$ $\left(1 \mathrm{C}, \mathrm{CH}_{2} \mathrm{O}\right), 172.02(1 \mathrm{C}, \mathrm{CON}) . \mathrm{MS}, m / z: 571(\mathrm{M}+\mathrm{H})^{+}$.

$N, N^{\prime}$-bis[1-oxo-1-(1-adamantyl)methyl]-4,10-diaza-12-crown-4 (12), $N, N^{\prime}$-bis[1-oxo-1(1-adamantyl)methyl]-4,10-diaza-15-crown-5 (13), N,N'-bis[1-oxo-1-(1-adamantyl)methyl]4,13-diaza-18-crown-6 (16), and N,N'-bis[2-(1-adamantyl)acetyl]-4,13-diaza-18-crown-6 (17) were synthesized as described previously $[16,54]$.

\subsubsection{General Procedure for Synthesis Compound 19}

To a suspension of $15 \mathrm{mmol} \mathrm{NaBH}_{4}$ in $20 \mathrm{~mL}$ of anhydrous THF, a solution of $15 \mathrm{mmol}$ boron trifluoride etherate in $20 \mathrm{~mL}$ of anhydrous THF was added dropwise with stirring. The temperature was brought to $50{ }^{\circ} \mathrm{C}$, and the reaction mixture was stirred for $30 \mathrm{~min}$ and cooled. The precipitate formed was filtered under reduced pressure. To the resulting filtrate, a solution of $0.015 \mathrm{~mol}$ of $\mathbf{1 3}$ in $30 \mathrm{~mL}$ THF was added for $30 \mathrm{~min}$ at room temperature. The reaction mixture was stirred at reflux for $4 \mathrm{~h}$ and cooled. Next, $15 \mathrm{~mL}$ of a $10 \% \mathrm{HCl}$ was added, and the reflux continued for additional $3 \mathrm{~h}$. After cooling, the mixture was neutralized with concentrated $\mathrm{NaOH}$ solution, the $\mathrm{pH}$ was adjusted to 9-10, and the reaction products were extracted with $\mathrm{CHCl}_{3}(5 \times 15 \mathrm{~mL})$. The combined extracts were dried with $\mathrm{MgSO}_{4}$. After removal of $\mathrm{CHCl}_{3}$ under reduced pressure, the product (19) was recrystallized twice from anhydrous hexane. 
N,N'-bis[(1-adamantyl)methyl]-4,10-diaza-15-crown-5 (19). Yield 94\%, light yellow crystals, MP 74-78 ${ }^{\circ} \mathrm{C}$. NMR ${ }^{1} \mathrm{H}\left(\mathrm{CDCl}_{3}\right) \delta_{\mathrm{H}}, 1.47-1.50(\mathrm{~m}, 12 \mathrm{H}, \mathrm{Ad}), 1.60-1.63(\mathrm{~m}, 6 \mathrm{H}, \mathrm{Ad})$, 1.68-1.70 (m, 6H, Ad), 1.93 (br.s, 6H, Ad), 2.11 (br.s, $\left.4 \mathrm{H}, \mathrm{CH}_{2}\right), 2.72-2.77\left(\mathrm{~m}, 8 \mathrm{H}, \mathrm{CH}_{2} \mathrm{~N}\right)$, 3.56-3.62 (m, $\left.12 \mathrm{H}, \mathrm{CH}_{2} \mathrm{O}\right) . \mathrm{NMR}^{13} \mathrm{C}\left(\mathrm{CDCl}_{3}\right) \delta_{\mathrm{C}}, 28.55(6 \mathrm{C}, \mathrm{Ad}), 35.10(2 \mathrm{C}, \mathrm{Ad}), 37.29(6 \mathrm{C}$, $\mathrm{Ad}), 41.14(6 \mathrm{C}, \mathrm{Ad}), 57.73\left(2 \mathrm{C}, \mathrm{CH}_{2} \mathrm{~N}\right), 57.78\left(2 \mathrm{C}, \mathrm{CH}_{2} \mathrm{~N}\right), 70.24\left(2 \mathrm{C}, \mathrm{CH}_{2} \mathrm{O}\right), 70.80\left(2 \mathrm{C}, \mathrm{CH}_{2}\right)$, $70.96\left(2 \mathrm{C}, \mathrm{CH}_{2} \mathrm{O}\right), 71.48\left(2 \mathrm{C}, \mathrm{CH}_{2} \mathrm{O}\right)$. MS, $m / z: 533(\mathrm{M}+\mathrm{H})^{+}$.

$\mathrm{N}$-[(1-adamantyl)methyl]aza-15-crown-5 (18), N,N'-bis[(1-adamantyl)methyl]-4,13diaza-18-crown-6 (20), and $N, N^{\prime}$-bis[2-(1-adamantyl)ethyl]-4,13-diaza-18-crown-6 (21) were synthesized as described previously $[16,54]$.

\subsubsection{General Procedure for Synthesis Compounds 22 and 23}

To a solution of $11 \mathrm{mmol}$ of 6-(Boc-amino)hexanoic acid, $1.49 \mathrm{~g}(11 \mathrm{mmol})$ of 1hydroxybenzotriazole in $5 \mathrm{~mL}$ of anhydrous dioxane and $15 \mathrm{~mL}$ of anhydrous dichlorometha ne, $2.27 \mathrm{~g}$ (11 mmol) of $N, N^{\prime}$-dicyclohexylcarbodiimide were added at room temperature. The mixture was stirred for $1 \mathrm{~h}$, and $5 \mathrm{mmol}$ of the corresponding diaza-crown ether was added. The mixture was stirred for additional $4-5 \mathrm{~h}$ (the reaction was monitored by TLC using $\mathrm{CHCl}_{3}$ :methanol:ammonia (25\%), 5:3:1 as eluent). Precipitated dicyclohexylurea was filtered and the organic phase was washed successively with $0.05 \mathrm{~N} \mathrm{HCl}$ $(4 \times 10 \mathrm{~mL}), \mathrm{H}_{2} \mathrm{O}(10 \mathrm{~mL}), \mathrm{Na}_{2} \mathrm{CO}_{3}$ solution $(0.05 \mathrm{~N})(4 \times 10 \mathrm{~mL}), \mathrm{H}_{2} \mathrm{O}(10 \mathrm{~mL})$ and dried with anhydrous $\mathrm{Na}_{2} \mathrm{SO}_{4}$. The solvent was evaporated to dryness under reduced pressure. The crude product was purified by column chromatography using ethyl acetate: methanol (20:1) as eluent. To remove the Boc protection, $10 \mathrm{~mL}$ of $4 \mathrm{~N} \mathrm{HCl}$ in ethyl acetate was added to a solution of $5 \mathrm{mmol}$ of the corresponding Boc derivative in $5 \mathrm{~mL}$ of anhydrous ethyl acetate. The reaction mixture was stirred for $1 \mathrm{~h}$, the solvent was removed to dryness on a rotary evaporator, and the product was dried under vacuum to constant weight.

$N, N^{\prime}$-bis(6-aminohexanoyl)-4,10-diaza-15-crown-5 dihydrochloride (22). Yield 94\%, light yellow crystals, MP $114-118^{\circ} \mathrm{C}$. NMR ${ }^{1} \mathrm{H}\left(\mathrm{DMSO}_{6} \mathrm{~d}_{6}\right) \delta_{\mathrm{H}}, 1.25$ (br.s, $\left.4 \mathrm{H}, \mathrm{CH}_{2}\right), 1.36$ (br.s, $4 \mathrm{H}$, $\mathrm{CH}_{2}$ ), 1.46 (br.s., $4 \mathrm{H}, \mathrm{CH}_{2}$ ), 2.25-2.29 (m, 4H, $\mathrm{CH}_{2}$ ), 2.56 (br.s, $2 \mathrm{H}, \mathrm{CH}_{2}$ ), 2.88 (br.s, $2 \mathrm{H}, \mathrm{CH}_{2}$ ), 3.45-3.61 (m, 20H, CH $\left.\mathrm{CH}_{2} \mathrm{O}\right)$. NMR ${ }^{13} \mathrm{C}\left(\mathrm{DMSO}^{\mathrm{d}} \mathrm{d}_{6}\right) \delta_{\mathrm{C}}, 25.12\left(2 \mathrm{C}, \mathrm{CH}_{2}\right), 26.55\left(2 \mathrm{C}, \mathrm{CH}_{2}\right), 32.75$ $\left(2 \mathrm{C}, \mathrm{CH}_{2}\right), 32.88\left(2 \mathrm{C}, \mathrm{CH}_{2}\right), 40.43\left(2 \mathrm{C}, \mathrm{CH}_{2}\right), 48.11\left(2 \mathrm{C}, \mathrm{CH}_{2} \mathrm{~N}\right), 49.44\left(2 \mathrm{C}, \mathrm{CH}_{2} \mathrm{~N}\right), 69.36(2 \mathrm{C}$, $\left.\mathrm{CH}_{2} \mathrm{O}\right), 70.09\left(2 \mathrm{C}, \mathrm{CH}_{2} \mathrm{O}\right), 70.68\left(2 \mathrm{C}, \mathrm{CH}_{2} \mathrm{O}\right), 172.97(2 \mathrm{C}, \mathrm{CON}) . \mathrm{MS}, m / z: 445(\mathrm{M}+\mathrm{H})^{+}$.

$N, N^{\prime}$-bis(6-aminohexanoyl)-4,10-diaza-12-crown-4 dihydrochloride (23). Yield 93\%, light yellow oil. NMR ${ }^{1} \mathrm{H}\left(\right.$ DMSO-d $_{6}$ ) $\delta_{\mathrm{H}}, 1.24$ (br.s, $4 \mathrm{H}, \mathrm{CH}$ ), 1.36 (br.s, $4 \mathrm{H}, \mathrm{CH}_{2}$ ), 1.45 (br.s, $4 \mathrm{H}$, $\mathrm{CH}_{2}$ ), 2.27-2.29 (m, 4H, $\left.\mathrm{CH}_{2}\right), 2.56$ (br.s, $\left.2 \mathrm{H}, \mathrm{CH}_{2}\right), 2.87$ (br.s, $\left.2 \mathrm{H}, \mathrm{CH}_{2}\right), 3.33-3.35(\mathrm{~m}, 4 \mathrm{H}$, $\mathrm{CH}_{2} \mathrm{O}$ ), 3.42-3.43 (m, 4H, $\left.\mathrm{CH}_{2} \mathrm{O}\right), 3.49$ (br.s, $2 \mathrm{H}, \mathrm{CH}_{2} \mathrm{O}$ ), 3.55 (br.s, $\left.2 \mathrm{H}, \mathrm{CH}_{2} \mathrm{O}\right), 3.60-3.63(\mathrm{~m}$, $\left.4 \mathrm{H}, \mathrm{CH}_{2} \mathrm{O}\right) . \mathrm{NMR}{ }^{13} \mathrm{C}\left(\mathrm{DMSO}_{6}\right) \delta_{\mathrm{C}}, 24.98\left(2 \mathrm{C}, \mathrm{CH}_{2}\right), 26.51\left(2 \mathrm{C}, \mathrm{CH}_{2}\right), 26.66\left(2 \mathrm{C}, \mathrm{CH}_{2}\right)$, $33.12\left(2 \mathrm{C}, \mathrm{CH}_{2}\right), 40.83\left(2 \mathrm{C}, \mathrm{CH}_{2}\right), 48.30\left(1 \mathrm{C}, \mathrm{CH}_{2} \mathrm{~N}\right), 48.78\left(1 \mathrm{C}, \mathrm{CH}_{2} \mathrm{~N}\right), 49.94\left(1 \mathrm{C}, \mathrm{CH}_{2} \mathrm{~N}\right)$, $50.95\left(1 \mathrm{C}, \mathrm{CH}_{2} \mathrm{~N}\right), 67.97\left(1 \mathrm{C}, \mathrm{CH}_{2} \mathrm{O}\right), 68.35\left(1 \mathrm{C}, \mathrm{CH}_{2} \mathrm{O}\right), 69.39\left(1 \mathrm{C}, \mathrm{CH}_{2} \mathrm{O}\right), 69.55\left(1 \mathrm{C}, \mathrm{CH}_{2} \mathrm{O}\right)$, $173.16(2 \mathrm{C}, \mathrm{CON})$. MS, $m / z: 401(\mathrm{M}+\mathrm{H})^{+}$.

N,N'-bis[4-(aminomethyl)benzoyl]-4,13-diaza-18-crown-6 dihydrochloride (24) was synthesized as described previously [56].

\subsubsection{General Procedure for Synthesis Compounds 25-27}

To a solution of $10.5 \mathrm{mmol}$ of 6-(Boc-amino)hexanoic or 4-(Boc-aminomethyl)benzoic acid, $1.42 \mathrm{~g}$ (10.5 mmol) of 1-hydroxybenzotriazole in $5 \mathrm{~mL}$ of anhydrous dioxane and $15 \mathrm{~mL}$ of anhydrous dichloromethane, $2.17 \mathrm{~g}(10.5 \mathrm{mmol}) \mathrm{N}, \mathrm{N}^{\prime}$-dicyclohexylcarbodiimide were added at room temperature. The mixture was stirred for $1 \mathrm{~h}$, and $10 \mathrm{mmol}$ of aza15-crown-5 or aza-18-crown- 6 was added. The mixture was stirred for an additional $4-5 \mathrm{~h}$ (the reaction was monitored by TLC using $\mathrm{CHCl}_{3}$ :methanol:ammonia ( $25 \%$ ) 5:3:1 as eluent). Precipitated dicyclohexylurea was filtered, and the organic phase was washed successively with $0.05 \mathrm{~N} \mathrm{HCl}(4 \times 10 \mathrm{~mL}), \mathrm{H}_{2} \mathrm{O}(10 \mathrm{~mL}), \mathrm{Na}_{2} \mathrm{CO}_{3}$ solution $(0.05 \mathrm{~N})(4 \times 10 \mathrm{~mL}), \mathrm{H}_{2} \mathrm{O}$ $(10 \mathrm{~mL})$ and dried with anhydrous $\mathrm{Na}_{2} \mathrm{SO}_{4}$. The solvent was removed to dryness under reduced pressure. The crude product was purified by column chromatography using ethyl acetate: methanol (20:1) as eluent. To remove the Boc protection, $15 \mathrm{~mL}$ of $4 \mathrm{M} \mathrm{HCl}$ in ethyl 
acetate was added to a solution of $3.3 \mathrm{mmol}$ of the corresponding Boc derivative in $5 \mathrm{~mL}$ of anhydrous ethyl acetate. The reaction mixture was stirred for $1 \mathrm{~h}$, the solvent was removed to dryness on a rotary evaporator, and the product was dried under vacuum to constant weight. N-(6-aminohexanoyl)aza-18-crown-6 hydrochloride (25). Yield 96\%, light yellow oil. NMR ${ }^{1} \mathrm{H}\left(\mathrm{DMSO}_{\mathrm{d}}\right) \delta_{\mathrm{H}}, 1.28-1.31\left(\mathrm{~m}, 2 \mathrm{H}, \mathrm{CH}_{2}\right), 1.46-1.49\left(\mathrm{~m}, 2 \mathrm{H}, \mathrm{CH}_{2}\right), 1.54-1.57\left(\mathrm{~m}, 2 \mathrm{H}, \mathrm{CH}_{2}\right)$, 2.29-2.31 (m, 2H, CH $), 3.38-3.52\left(\mathrm{~m}, 26 \mathrm{H}, \mathrm{CH}_{2} \mathrm{O} ; \mathrm{CH}_{2}\right) . \mathrm{NMR}{ }^{13} \mathrm{C}\left(\mathrm{DMSO}_{6} \mathrm{~d}_{6}\right) \delta_{\mathrm{C}}, 24.75$ $\left(1 \mathrm{C}, \mathrm{CH}_{2}\right), 26.06\left(1 \mathrm{C}, \mathrm{CH}_{2}\right), 27.28\left(1 \mathrm{C}, \mathrm{CH}_{2}\right), 32.36\left(1 \mathrm{C}, \mathrm{CH}_{2}\right), 39.06\left(1 \mathrm{C}, \mathrm{CH}_{2}\right), 46.57(2 \mathrm{C}$, $\left.\mathrm{CH}_{2} \mathrm{~N}\right), 69.09\left(2 \mathrm{C}, \mathrm{CH}_{2} \mathrm{O}\right), 70.20\left(2 \mathrm{C}, \mathrm{CH}_{2} \mathrm{O}\right), 70.36\left(2 \mathrm{C}, \mathrm{CH}_{2} \mathrm{O}\right), 70.52\left(2 \mathrm{C}, \mathrm{CH}_{2} \mathrm{O}\right), 70.63$ $\left(2 \mathrm{C}, \mathrm{CH}_{2} \mathrm{O}\right), 172.46(\mathrm{C}, \mathrm{CON}) . \mathrm{MS}, \mathrm{m} / z: 377(\mathrm{M}+\mathrm{H})^{+}$.

N-(6-aminohexanoyl)aza-15-crown-5 hydrochloride (26). Yield 90\%, light yellow oil. NMR ${ }^{1} \mathrm{H}\left(\mathrm{DMSO}_{-} \mathrm{d}_{6}\right) \delta_{\mathrm{H}}, 1.28-1.31\left(\mathrm{~m}, 2 \mathrm{H}, \mathrm{CH}_{2}\right), 1.46-1.50\left(\mathrm{~m}, 2 \mathrm{H}, \mathrm{CH}_{2}\right), 1.54-1.58(\mathrm{~m}, 2 \mathrm{H}$, $\left.\mathrm{CH}_{2}\right), 2.27-2.30\left(\mathrm{~m}, 2 \mathrm{H}, \mathrm{CH}_{2}\right), 3.00-3.10\left(\mathrm{~m}, 2 \mathrm{H} \mathrm{CH}_{2}\right), 3.39-3.55\left(\mathrm{~m}, 20 \mathrm{H}, \mathrm{CH}_{2} \mathrm{O}\right)$. NMR ${ }^{13} \mathrm{C}$ $\left(\mathrm{DMSO}_{6}\right) \delta_{\mathrm{C}}, 24.43\left(1 \mathrm{C}, \mathrm{CH}_{2}\right), 25.86\left(1 \mathrm{C}, \mathrm{CH}_{2}\right), 27.09\left(1 \mathrm{C}, \mathrm{CH}_{2}\right), 32.47\left(1 \mathrm{C}, \mathrm{CH}_{2}\right), 39.01$ $\left(1 \mathrm{C}, \mathrm{CH}_{2}\right), 49.58\left(2 \mathrm{C}, \mathrm{CH}_{2} \mathrm{~N}\right), 66.02\left(2 \mathrm{C}, \mathrm{CH}_{2} \mathrm{O}\right), 69.85\left(2 \mathrm{C}, \mathrm{CH}_{2} \mathrm{O}\right), 70.21\left(2 \mathrm{C}, \mathrm{CH}_{2} \mathrm{O}\right), 70.69$ (2C, $\left.\mathrm{CH}_{2 \mathrm{O}} \mathrm{O}\right), 174.77(1 \mathrm{C}, \mathrm{CON}) . \mathrm{MS}, \mathrm{m} / z: 333(\mathrm{M}+\mathrm{H})^{+}$.

N-[4-(aminomethyl)benzoyl)aza-15-crown-5 hydrochloride (27). Yield 91\%, light yellow oil. $\mathrm{NMR}{ }^{1} \mathrm{H}\left(\mathrm{DMSO}_{-} \mathrm{d}_{6}\right) \delta_{\mathrm{H}}, 3.40-3.56\left(\mathrm{~m}, 2 \mathrm{H}, \mathrm{CH}_{2} \mathrm{O}\right), 3.69-3.77\left(\mathrm{~m}, 2 \mathrm{H}, \mathrm{ArCH}_{2} \mathrm{~N}\right), 7.38-7.40$ $(\mathrm{d}, J 7.5 \mathrm{~Hz}, 2 \mathrm{H}, \mathrm{Ar}), 7.55-7.57(\mathrm{~d}, J 7.5 \mathrm{~Hz}, 2 \mathrm{H}, \mathrm{Ar}) . \mathrm{NMR}{ }^{13} \mathrm{C}\left(\mathrm{DMSO}-\mathrm{d}_{6}\right) \delta_{\mathrm{C}}, 42.26(1 \mathrm{C}$, $\left.\mathrm{CH}_{2} \mathrm{NH}_{2}\right), 47.33\left(2 \mathrm{C}, \mathrm{CH}_{2} \mathrm{~N}\right), 69.89\left(2 \mathrm{C}, \mathrm{CH}_{2} \mathrm{O}\right), 70.01\left(2 \mathrm{C}, \mathrm{CH}_{2} \mathrm{O}\right), 70.21\left(2 \mathrm{C}, \mathrm{CH}_{2} \mathrm{O}\right), 70.81$ (2C, $\left.\mathrm{CH}_{2} \mathrm{O}\right), 127.17$ (2C, Ar), 130.31 (2C, Ar), 137.40 (1C, Ar), 140.09 (1C, Ar), 171.02 (1C, $\mathrm{CON}) . \mathrm{MS}, m / z: 353(\mathrm{M}+\mathrm{H})^{+}$.

N,N'-bis(carboxymethyl)-4,13-diaza-18-crown-6 (28) was synthesized as described in paper [34].

\subsection{Biological Methods}

\subsubsection{Materials for Biological Studies}

Dimethyl sulfoxide (DMSO), N-formyl Met-Leu-Phe ( $f$ MLF), phorbol 12-myristate 13-acetate (PMA), HEPES, and Histopaque 1077 were from Sigma Chemical Co. (St. Louis, MO, USA). RPMI 1640 medium and penicillin-streptomycin solution were from Mediatech (Herdon, VA, USA). Fetal bovine serum (FBS) was from Atlas Biologicals (Fort Collins, CO, USA). Peptide Trp-Lys-Tyr-Met-Val-Met (WKYMVM) was from Tocris Bioscience (Ellisville, MO, USA). Hanks' balanced salt solution (HBSS), Fluo-4 AM, and G418 were from Life Technologies (Grand Island, NY, USA). HBSS containing $1.3 \mathrm{mM} \mathrm{CaCl} 2$ and

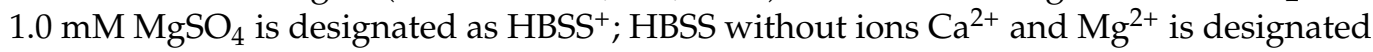
as $\mathrm{HBSS}^{-}$. Fluorescein isothiocyanate (FITC) was conjugated to the lysine residue of TrpLys-Tyr-Met-Val-D-Met (WKYMVm) to produce a fluorescent ligand (WKYMVm-FITC) that binds to FPR1 (custom synthesis by Bachem, Torrance, CA, USA). All synthesized compounds for biological testing were dissolved in DMSO at $5 \mathrm{mM}$ stock concentration and stored at $-20^{\circ} \mathrm{C}$.

\subsubsection{Cell Culture}

Human promyelocytic leukemia HL60 cells stably transfected with FPR1 (FPR1-HL60 cells) or FPR2 (FPR2-HL60 cells) (kind gifts from Dr. Marie-Josephe Rabiet, INSERM, Grenoble, France) were cultured in RPMI 1640 medium supplemented with 10\% heatinactivated fetal calf serum, $10 \mathrm{mM}$ HEPES, $100 \mu \mathrm{g} / \mathrm{mL}$ streptomycin, $100 \mathrm{U} / \mathrm{mL}$ penicillin, and G418 (1 mg/mL). Although stable cell lines are cultured under G418 selection pressure, G418 may affect some assays, so it was removed in the last round of culture before assays were performed.

\subsubsection{Isolation of Human Neutrophils}

For isolation of human neutrophils, blood was collected from healthy donors in accordance with a protocol approved by the Institutional Review Board at Montana State University. Neutrophils were purified from the blood using dextran sedimentation, followed by Histopaque 1077 gradient separation and hypotonic lysis of red blood cells, 
as described previously [57]. Isolated neutrophils were washed twice and resuspended in HBSS $^{-}$. Neutrophil preparations were routinely $>95 \%$ pure, as determined by light microscopy, and $>98 \%$ viable, as determined by trypan blue exclusion. Neutrophils were obtained from multiple different donors; however, the cells from different donors were never pooled during experiments.

\subsection{4. $\mathrm{Ca}^{2+}$ Mobilization Assay}

Changes in neutrophil intracellular $\mathrm{Ca}^{2+}$ concentrations $\left(\left[\mathrm{Ca}^{2+}\right]_{\mathrm{i}}\right)$ were measured with a FlexStation 3 scanning fluorometer (Molecular Devices, Sunnyvale, CA, USA). Briefly, human neutrophils were suspended in HBSS $^{-}$, loaded with Fluo-4AM at a final concentration of $1.25 \mu \mathrm{g} / \mathrm{mL}$, and incubated for $30 \mathrm{~min}$ in the dark at $37^{\circ} \mathrm{C}$. After dye loading, the cells were washed with $\mathrm{HBSS}^{-}$, resuspended in $\mathrm{HBSS}^{+}$, separated into aliquots, and loaded into the wells of flat-bottom, half-area well black microtiter plates $\left(2 \times 10^{5}\right.$ cells / well). To assess the direct effects of test compounds on $\mathrm{Ca}^{2+}$ flux, the compounds were added to the wells (final concentration of DMSO was $1 \%$ ), and changes in fluorescence were monitored $\left(\lambda_{\mathrm{ex}}=485 \mathrm{~nm}, \lambda_{\mathrm{em}}=538 \mathrm{~nm}\right)$ every $5 \mathrm{~s}$ for $240 \mathrm{~s}$ at room temperature after addition of the test compound. To evaluate inhibitory effects of the compounds on FPR1/FPR2-dependent $\mathrm{Ca}^{2+}$ flux, the compounds were added to the wells (final concentration of DMSO was $1 \%$ ) with cells (human neutrophils or FPR1/FPR2 HL60 cells). The samples were preincubated for $10 \mathrm{~min}$, followed by addition of $5 \mathrm{nM} f \mathrm{MLF}$ (for human neutrophils or FPR1-HL60 cells) or $5 \mathrm{nM}$ WKYMVM (for FPR2-HL60 cells). The maximum change in fluorescence, expressed in arbitrary units over baseline, was used to determine the agonist response. Responses were normalized to the response induced by $5 \mathrm{nM} f$ MLF or $5 \mathrm{nM}$ WKYMVM, which were assigned as $100 \%$. Curve fitting (at least five or six points) and calculation of median effective concentration values $\left(\mathrm{EC}_{50}\right.$ or $\left.\mathrm{IC}_{50}\right)$ were performed by nonlinear regression analysis of the dose-response curves generated using Prism 7 (GraphPad Software, Inc., San Diego, CA, USA). Efficacy was determined by comparing individual responses activated by the test compounds to that induced by a positive control ( $5 \mathrm{nM} f \mathrm{MLF}$ ), which was assigned a value of $100 \%$.

\subsubsection{Chemotaxis Assay}

Human neutrophils were suspended in $\mathrm{HBSS}^{+}$containing $2 \%(v / v)$ heat-inactivated fetal bovine serum $\left(2 \times 10^{6}\right.$ cells $\left./ \mathrm{mL}\right)$, and effects of the compounds on $f$ MLF-induced chemotaxis was analyzed in 96-well ChemoTx chemotaxis chambers (Neuroprobe, Gaithersburg, MD). In brief, neutrophils were preincubated with the indicated concentrations of the test compounds or DMSO for $20 \mathrm{~min}$ at room temperature and added to the upper wells of the ChemoTx chemotaxis chambers. The lower wells were loaded with $30 \mu \mathrm{L}$ of $\mathrm{HBSS}^{+}$containing $2 \%$ $(v / v)$ fetal bovine serum and the indicated concentrations of test sample plus $1 \mathrm{nM} f \mathrm{MLF}$, DMSO (negative control), or $1 \mathrm{nM} f \mathrm{MLF}$ as a positive control. Neutrophils were added to the upper wells and allowed to migrate through the $5.0-\mu \mathrm{m}$ pore polycarbonate membrane filter for $60 \mathrm{~min}$ at $37{ }^{\circ} \mathrm{C}$ and $5 \% \mathrm{CO}_{2}$. The number of migrated cells was determined by measuring ATP in lysates of transmigrated cells using a luminescence-based assay (CellTiterGlo; Promega, Madison, WI, USA), and luminescence measurements were converted to absolute cell numbers by comparison of the values with standard curves obtained with known numbers of neutrophils. Curve fitting (at least eight to nine points) and calculation of median effective concentration values $\left(\mathrm{IC}_{50}\right)$ were performed by nonlinear regression analysis of the dose-response curves generated using Prism 5.

\subsubsection{Competition Binding Assay}

Competition binding assays were performed to measure compound competition with the high-affinity fluorescent ligand WKYMVm-FITC for binding to human FPR1HL60 cells, as described previously [38]. Briefly, FPR1-HL60 cells were preincubated with different concentrations of test compound for $30 \mathrm{~min}$ at $4{ }^{\circ} \mathrm{C}$, followed by addition of $0.5 \mathrm{nM}$ WKYMVm-FITC. After incubation for an additional $30 \mathrm{~min}$ at $4{ }^{\circ} \mathrm{C}$, the samples 
were immediately analyzed using flow cytometry (LSRII, BD Biosciences, San Jose, CA, USA) without washing. The assay response range was defined by replicate control samples containing $1 \mu \mathrm{M}$ of unlabeled $f \mathrm{MLF}$ (positive control) or buffer (negative control). The ligand competition curves were fitted by Prism software using nonlinear least-squares regression in a sigmoidal dose-response model to determine the concentration of added test compound that inhibited fluorescent ligand binding by $50 \%$ (i.e., $\mathrm{IC}_{50}$ ).

\subsubsection{ROS Production}

ROS production was determined by monitoring L-012-enhanced chemiluminescence, which represents a sensitive and reliable method for detecting superoxide anion $\left(\mathrm{O}_{2}{ }^{-}\right)$ production. Human neutrophils were resuspended at $2 \times 10^{5}$ cells $/ \mathrm{mL}$ in $\mathrm{HBSS}^{+}$supplemented with $40 \mu \mathrm{M} \mathrm{L}-012$. Cells $(100 \mu \mathrm{L})$ were aliquoted into wells of 96 -well flat-bottomed microtiter plates containing test compounds at different concentrations (final DMSO concentration of $1 \%$ ). Cells were preincubated for $10 \mathrm{~min}$, and $200 \mathrm{nM}$ PMA was added to each well to stimulate ROS production. Luminescence was monitored for $120 \mathrm{~min}$ (2-min intervals) at $37^{\circ} \mathrm{C}$ using a Fluroscan Ascent FL microtiter plate reader (Thermo Electron, Waltham, MA, USA). The curve of light intensity (in relative luminescence units) was plotted against time, and the area under the curve was calculated as total luminescence. The compound concentration that inhibited ROS production by $50 \%$ of the PMA-induced response (positive control) was determined by graphing the percentage inhibition of ROS production versus the logarithm of concentration of test sample $\left(\mathrm{IC}_{50}\right)$. Each curve was determined using five to seven concentrations.

\subsubsection{Assessment of Compound Cytotoxicity}

Human promyelocytic leukemia HL60 cells were cultured in RPMI-1640 medium supplemented with 10\% heat-inactivated FBS, $10 \mathrm{mM}$ HEPES, $100 \mu \mathrm{g} / \mathrm{mL}$ streptomycin, and $100 \mathrm{U} / \mathrm{mL}$ penicillin. Cytotoxicity was analyzed with a CellTiter-Glo Luminescent Cell Viability Assay Kit (Promega, Madison, WI, USA), according to the manufacturer's protocol. Briefly, wild-type HL60 cells were cultured at a density of $1 \times 10^{5}$ cells/well with different concentrations of the compounds under investigation for $90 \mathrm{~min}$ at $37^{\circ} \mathrm{C}$ and $5 \%$ $\mathrm{CO}_{2}$. Following treatment, the cells were allowed to equilibrate to room temperature for $30 \mathrm{~min}$, substrate was added, and the samples were analyzed with a Fluoroscan Ascent FL microplate reader.

\subsection{Molecular Modeling}

Crown and aza-crown ethers are very conformationally flexible compounds. Therefore, a preliminary conformational search was performed for molecules 12-15, and 19, by the molecular mechanics method (MM+ force field) with the use of HyperChem 7 software. In this conformational search, all torsion angles inside the macrocycle and two exocyclic torsion angles about $\mathrm{C}-\mathrm{N}$ bonds were varied. For compound 15, the torsion angles about the carbon-carbon bonds of the $\mathrm{O}=\mathrm{C}-\mathrm{CH}_{2}$ fragments were additionally varied. Local geometry optimizations (5000) were made (10,000 optimizations for compound 15), and 1000 conformations were kept within a $10 \mathrm{kcal} / \mathrm{mol}$ energy gap from the lowest energy conformation. Among these, 30 of the most optimal conformations (50 for molecule 15) were selected, for which additional geometry optimizations were performed by the semiempirical PM3 method with HyperChem 7 program. Finally, 10 conformations of each aza-crown ether with the lowest PM3 energies were further optimized by the DFT method with the BLYP functional using the Gaussian 16 software (Gaussian, Inc., Wallingford CT).

In DFT calculations of macrocyclic ligands, complexes of $\mathrm{Na}^{+}, \mathrm{K}^{+}$, and $\mathrm{Ca}^{2+}$ with these ligands, and of the unbound ions, the def2-SVP basis set was used for $\mathrm{C}$ and $\mathrm{H}$ atoms. For $\mathrm{N}, \mathrm{O}, \mathrm{Na}^{+}, \mathrm{K}^{+}$, and $\mathrm{Ca}^{2+}$ participating in the formation of coordination bonds, the extended def2-TZVP basis set [58] was applied. Dispersion interactions were taken into account using the D3BJ model [59]. The attainment of the minimum on a potential energy surface for each investigated structure was confirmed by the absence of imaginary frequencies of 
normal vibrations. The binding energy in the gas phase on the formation of complexes was calculated by the equation:

$$
\Delta \mathrm{U}=\mathrm{E}\left(\mathrm{M}^{\mathrm{n}+} \cdot \text { ligand }\right)-\left[\mathrm{E}\left(\mathrm{M}^{\mathrm{n}+}\right)+\mathrm{E}(\text { ligand })\right],
$$

where $\mathrm{E}\left(\mathrm{M}^{\mathrm{n}+}\right.$.ligand), $\mathrm{E}\left(\mathrm{M}^{\mathrm{n}+}\right)(\mathrm{n}=1$ or 2$)$ and $\mathrm{E}($ ligand) represent energies of the complex, metal ion, and free ligand, respectively, including thermal corrections to the energy at $298.15 \mathrm{~K}$ and corrections for zero-point vibrations [44]. In Equation (3), the values of $\mathrm{E}\left(\mathrm{M}^{\mathrm{n}+} \cdot\right.$ ligand $)$ and $\mathrm{E}$ (ligand) correspond to the complex and ligand in their lowest-energy conformations.

The basis set superposition error (BSSE), which is significant in the DFT calculations of coordination compounds, was taken into account using a counterpoise correction [60], as it was previously used for complexes of s-elements and transition metal ions with crown ethers (see, for example [43,44]). The DFT results were visualized using GaussView 6.

Compound physicochemical properties were computed using the SwissADME web server (http:/ / www.swissadme.ch, accessed on 26 January 2021). Regression analyses were performed using STATISTICA 6 software.

\section{Conclusions}

We report the synthesis and analysis of twenty-four aza- and diaza-crown ethers with adamantyl, adamantylalkyl, 4-(aminomethyl)benzoyl, and $\varepsilon$-aminocaproyl substituents. This is the first report of the synthesis of compounds 10, 11, 14, 15, 19, 22, 23, and 2527. Ten of the compounds $(\mathbf{8}, \mathbf{1 0 - 1 7}$, and 21$)$ caused a concentration-dependent increase in $\left[\mathrm{Ca}^{2+}\right]_{\mathrm{i}}$ in human neutrophils. On the other hand, compounds 8, 10, 13-17, and 21 inhibited neutrophil activation by the chemotactic peptide $f M L F$, resulting in inhibition of $f$ MLF-induced $\left[\mathrm{Ca}^{2+}\right]_{i}$ flux. Some of these compounds also inhibited neutrophil ROS production and chemotaxis, as well as $\left[\mathrm{Ca}^{2+}\right]_{\mathrm{i}}$ flux in FPR-transfected HL60 cells. DFT analysis showed that $\mathrm{Ca}^{2+}$ ions bound more effectively to these crown ethers versus $\mathrm{Na}^{+}$ and $\mathrm{K}^{+}$. Moreover, DFT-optimized structures of the ligand-Ca ${ }^{2+}$ complexes and QSAR models demonstrated that the carbonyl oxygen atoms of these aza- and diaza-crown ethers participated in cation binding and can play an important role in $\mathrm{Ca}^{2+}$ transfer. Thus, this modeling provides a molecular basis to explain at least part of the ionophore mechanism of biological action of these crown ethers and may help elucidate mechanisms of $\mathrm{Ca}^{2+}$ transfer across neutrophil membranes facilitated by mobile ion carriers. Future studies are now in progress to evaluate the anti-inflammatory and immunomodulatory potential of these crown ethers.

Author Contributions: S.S.B., I.A.S., A.I.K., and M.T.Q. designed and supervised the work; A.F.L. and T.I.K. performed the chemical synthesis and full characterization; S.S.B., A.F.L., V.I.P., K.A.L., and D.A.V. analyzed the analytical data; I.A.S. and L.N.K. performed the biological experiments; A.I.K. conducted molecular modeling; S.S.B., I.A.S., and A.I.K. wrote the manuscript; S.S.B., I.A.S., A.I.K., and M.T.Q. edited the manuscript. All authors have read and agreed to the submitted version of the manuscript.

Funding: This research was supported in part by National Institutes of Health IDeA Program Grants GM115371 and GM103474; USDA National Institute of Food and Agriculture Hatch project 1009546; the Montana State University Agricultural Experiment Station; the Ministry of Science and Higher Education of the Russian Federation (project Nauka FSWW-2020-0011); and the Tomsk Polytechnic University Competitiveness Enhancement Program.

Institutional Review Board Statement: The study was conducted according to the guidelines of the Declaration of Helsinki and approved by the Institutional Review Board of Montana State University (protocol MQ040107, approved 1 April 2017)

Informed Consent Statement: Informed consent was obtained from all subjects involved in this study.

Data Availability Statement: The data that support the findings of this study are available from the authors upon reasonable request.

Conflicts of Interest: The authors declare no conflict of interest. 
Sample Availability: Samples of the compounds are available from the authors.

\section{References}

1. Alfonso, I.; Quesada, R. Biological activity of synthetic ionophores: Ion transporters as prospective drugs? Chem. Sci. 2013, 4, 3009-3019. [CrossRef]

2. Pedersen, C.J. Cyclic polyethers and their complexes with metal salts. J. Am. Chem. Soc. 1967, 89, 2495-2496, 7017-7036. [CrossRef]

3. Moczar, I.; Huszthy, P. Optically active crown ether-based fluorescent sensor molecules: A mini-review. Chirality 2019, 31, 97-109. [CrossRef] [PubMed]

4. Li, J.; Yim, D.; Jang, W.D.; Yoon, J. Recent progress in the design and applications of fluorescence probes containing crown ethers. Chem. Soc. Rev. 2017, 46, 2437-2458. [CrossRef] [PubMed]

5. Yu, L.; Li, F.Z.; Wu, J.Y.; Xie, J.Q.; Li, S. Development of the aza-crown ether metal complexes as artificial hydrolase. J. Inorg. Biochem. 2016, 154, 89-102. [CrossRef]

6. Otis, F.; Auger, M.; Voyer, N. Exploiting peptide nanostructures to construct functional artificial ion channels. Acc. Chem. Res. 2013, 46, 2934-2943. [CrossRef]

7. Gokel, G.W. Hydraphiles: Design, synthesis and analysis of a family of synthetic, cation-conducting channels. Chem. Commun. 2000, 1-9. [CrossRef]

8. Kralj, M.; Tusek-Bozic, L.; Frkanec, L. Biomedical potentials of crown ethers: Prospective antitumor agents. ChemMedChem 2008, 3, 1478-1492. [CrossRef]

9. Tso, W.W.; Fung, W.P.; Tso, M.Y.W. Variability of crown ether toxicity. J. Inorg. Biochem. 1981, 14, 237-244. [CrossRef]

10. Karawajew, L.; Glibin, E.N.; Maleev, V.Y.; Czerwony, G.; Dorken, B.; Davies, D.B.; Veselkov, A.N. Role of crown-like side chains in the biological activity of substituted-phenoxazone drugs. Anti-Cancer Drug Des. 2000, 15, 331-338.

11. Fukuda, R.; Takenaka, S.; Takagi, M. Metal-ion assisted DNA-intercalation of crown ether-linked acridine-derivatives. J. Chem. Soc. Chem. Comm. 1990, 1028-1030. [CrossRef]

12. Adamovich, S.N.; Mirskova, A.N.; Mirskov, R.G.; Perminova, O.M.; Chipanina, N.N.; Aksamentova, T.N.; Voronkov, M.G. New quaternary ammonium salts and metal complexes of organylheteroacetic acids with diaza-18-crown-6 ether. Russ. J. Gen. Chem. 2010, 80, 1007-1010. [CrossRef]

13. Marjanovic, M.; Kralj, M.; Supek, F.; Frkanec, L.; Piantanida, I.; Smuc, T.; Tusek-Bozic, L. Antitumor potential of crown ethers: Structure-activity relationships, cell cycle disturbances, and cell death studies of a series of ionophores. J. Med. Chem. 2007, 50, 1007-1018. [CrossRef] [PubMed]

14. Zasukhina, G.A.; Vasil'eva, I.M.; Vedernikov, A.I.; Gromov, S.P.; Alfimov, M.V. Antimutagenic characteristics of new diazacrown compounds with n-carboxyalkyl substitutes. Bull. Exp. Biol. Med. 2006, 141, 331-333. [CrossRef] [PubMed]

15. Gredicak, M.; Supek, F.; Kralj, M.; Majer, Z.; Hollosi, M.; Smuc, T.; Mlinaric-Majerski, K.; Horvat, S. Computational structureactivity study directs synthesis of novel antitumor enkephalin analogs. Amino Acids 2010, 38, 1185-1191. [CrossRef] [PubMed]

16. Supek, F.; Ramljak, T.S.; Marjanovic, M.; Buljubasic, M.; Kragol, G.; Ilic, N.; Smuc, T.; Zahradka, D.; Mlinaric-Majerski, K.; Kralj, M. Could LogP be a principal determinant of biological activity in 18-crown-6 ethers? Synthesis of biologically active adamantane-substituted diaza-crowns. Eur. J. Med. Chem. 2011, 46, 3444-3454. [CrossRef]

17. Guberovic, I.; Marjanovic, M.; Mioc, M.; Ester, K.; Martin-Kleiner, I.M.; Ramljak, T.S.; Mlinaric-Majerski, K.M.; Kralj, M. Crown ethers reverse p-glycoprotein-mediated multidrug resistance in cancer cells. Sci. Rep. 2018, 8, 14467. [CrossRef] [PubMed]

18. Hasanova, U.A.; Ramazanov, M.A.; Maharramov, A.M.; Gakhramanova, Z.; Hajiyeva, S.F.; Vezirova, L.; Eyvazova, G.M.; Hajiyeva, F.V.; Huseynova, P.; Agamaliyev, Z. The functionalization of magnetite nanoparticles by hydroxyl substituted diazacrown ether, able to mimic natural siderophores, and investigation of their antimicrobial activity. J. Incl. Phenom. Macrocycl. Chem. 2016, 86, 19-25. [CrossRef]

19. Cantwell, R.; Garrad, E.C.; Gokel, M.R.; Hayes, M.J.; Meisel, J.W.; Negin, S.; Patel, M.B.; Gokel, G.W. Biological activity of macrocyclic cation transporters. Curr. Org. Chem. 2015, 19, 2229-2236. [CrossRef]

20. Negin, S.; Patel, M.B.; Gokel, M.R.; Meisel, J.W.; Gokel, G.W. Antibiotic potency against E. coli is enhanced by channel-forming alkyl lariat ethers. ChemBioChem 2016, 17, 2153-2161. [CrossRef]

21. Gurbanov, K.G.; Paperno, A.A.; Spasov, A.A.; Vasil'ev, P.M.; Breslaukhov, A.G.; Luk'ianenko, N.G.; Basok, S.S.; Kulygina, E.; Bogashchenko, T. The relationship between the magnitude of the negative inotropic action and chemical structure of crown-ether derivatives. Eksp. Klin. Farm. 1993, 56, 32-34.

22. Samiei, E.F.; Boojar, M.M.A.; Moradi-Sardareh, H. The effects of macrocyclic dinaphtho diamide on the oxidative states and stimulating the csf production lung tissue and colony formation of bone marrow cells. J. Incl. Phenom. Macrocycl. Chem. 2017, 87, 259-266. [CrossRef]

23. Voronina, T.A.; Karasyova, T.L.; Golovenko, N.Y.; Rokachinskaya, M.G.; Basok, S.S.; Sharapova, S.E.; Kulygina, E.Y.; Lukyanenko, N.G. Psychotropic properties of aza-15-crown-5 derivatives with pharmacophoric groups. Khimiko-Farmatsevticheskii Zhurnal 1988, 22, 679-682. [CrossRef]

24. Karaseva, T.L.; Tsapenko, Z.N.; Golovenko, N.; Timofeeva, S.E.; Luk'ianenko, N.G. Gamma-aminobutyric acid metabolism in the rat brain after administration of nootropic agents. Vopr. Med. Khim. 1988, 34, 81-84. 
25. Lukyanenko, N.G.; Bogatsky, A.V.; Voronina, T.A.; Golovenko, N.Y.; Karaseva, T.L.; Timofeeva, S.E.; Basok, S.S.; Pastushok, V.N.; Garibova, T.L.; Kostyanovsky, R.G. Macroheterocycles; XXIII. Antihypoxic and antiamnesic activity of azacrown esters with pharmacophoric groups. Khimiko-Farmatsevticheskii Zhurnal 1985, 19, 691-693. [CrossRef]

26. Zabirov, N.G.; Pozdeev, O.K.; Shcherbakova, V.A.; Shumilova, T.N.; Gilmanova, G.K.; Cherkasov, R.A. Phosphorus-containing derivatives of diaza-18-crown-6. Khimiko-Farmatsevticheskii Zhurnal 1990, 24, 51-53.

27. Famaey, J.P.; Whitehouse, M.W. About some possible anti-inflammatory properties of various membrane permeant agents. Agents Actions 1975, 5, 133-136. [CrossRef]

28. Kiss, E.; Balazs, C.; Bene, L.; Damjanovich, S.; Matko, J. Effect of TSH and anti-TSH receptor antibodies on the plasma membrane potential of polymorphonuclear granulocytes. Immunol. Lett. 1997, 55, 173-177. [CrossRef]

29. Divirgilio, F.; Lew, P.D.; Andersson, T.; Pozzan, T. Plasma-membrane potential modulates chemotactic peptide-stimulated cytosolic free $\mathrm{Ca}^{2+}$ changes in human-neutrophils. J. Biol. Chem. 1987, 262, 4574-4579. [CrossRef]

30. de Oliveira, R.M.; Antunes, E.; Pedrazzoli, J.; Gambero, A. The inhibitory effects of $\mathrm{H}^{+} \mathrm{K}^{+}$ATPase inhibitors on human neutrophils in vitro: Restoration by a $\mathrm{K}^{+}$ionophore. Inflamm. Res. 2007, 56, 105-111. [CrossRef]

31. Demaurex, N.; Downey, G.P.; Waddell, T.K.; Grinstein, S. Intracellular pH regulation during spreading of human neutrophils. J. Cell. Biol. 1996, 133, 1391-1402. [CrossRef]

32. Calafat, J.; Janssen, H.; Knol, E.F.; Malm, J.; Egesten, A. The bactericidal/permeability-increasing protein (BPI) is membraneassociated in azurophil granules of human neutrophils, and relocation occurs upon cellular activation. Apmis 2000, 108, 201-208. [CrossRef] [PubMed]

33. Fittschen, C.; Henson, P.M. Linkage of azurophil granule secretion in neutrophils to chloride-ion transport and endosomal transcytosis. J. Clin. Investig. 1994, 93, 247-255. [CrossRef] [PubMed]

34. Kulstad, S.; Malmsten, L.A. Diaza-crown ethers.1. Alkali ion promoted formation of diaza-crown ethers and syntheses of some $N, N^{\prime}$-disubstituted derivatives. Acta Chem. Scand. B 1979, 33, 469-474. [CrossRef]

35. Schaff, U.Y.; Yamayoshi, I.; Tse, T.; Griffin, D.; Kibathi, L.; Simon, S.I. Calcium flux in neutrophils synchronizes beta2 integrin adhesive and signaling events that guide inflammatory recruitment. Ann. Biomed. Eng. 2008, 36, 632-646. [CrossRef]

36. Krause, K.H.; Campbell, K.P.; Welsh, M.J.; Lew, D.P. The calcium signal and neutrophil activation. Clin. Biochem. 1990, 23, 159-166. [CrossRef]

37. Stenfeldt, A.L.; Karlsson, J.; Wenneras, C.; Bylund, J.; Fu, H.; Dahlgren, C. Cyclosporin H, Boc-MLF and Boc-FLFLF are antagonists that preferentially inhibit activity triggered through the formyl peptide receptor. Inflammation 2007, 30, 224-229. [CrossRef]

38. Schepetkin, I.A.; Kirpotina, L.N.; Khlebnikov, A.I.; Cheng, N.; Ye, R.D.; Quinn, M.T. Antagonism of human formyl peptide receptor 1 (FPR1) by chromones and related isoflavones. Biochem. Pharm. 2014, 92, 627-641. [CrossRef] [PubMed]

39. Steinckwich, N.; Schenten, V.; Melchior, C.; Brechard, S.; Tschirhart, E.J. An essential role of STIM1, Orai1, and S100A8-A9 proteins for $\mathrm{Ca}^{2+}$ signaling and $\mathrm{F} c \gamma \mathrm{R}$-mediated phagosomal oxidative activity. J. Immunol. 2011, 186, 2182-2191. [CrossRef]

40. Fay, A.J.; Qian, X.; Jan, Y.N.; Jan, L.Y. Sk channels mediate NADPH oxidase-independent reactive oxygen species production and apoptosis in granulocytes. Proc. Natl. Acad. Sci. USA 2006, 103, 17548-17553. [CrossRef]

41. Mahajan, R.K.; Kumar, M.; Sharma Nee Bhalla, V.; Kaur, I. Cesium ion selective electrode based on calix[4]crown ether-ester Talanta 2002, 58, 445-450. [CrossRef]

42. Suzuki, K.; Sato, K.; Hisamoto, H.; Siswanta, D.; Hayashi, K.; Kasahara, N.; Watanabe, K.; Yamamoto, N.; Sasakura, H. Design and synthesis of sodium ion-selective ionophores based on 16-crown-5 derivatives for an ion-selective electrode. Anal. Chem. 1996, 68, 208-215. [CrossRef]

43. Islam, N.; Chimni, S.S. Binding and selectivity of phenazino-18-crown-6-ether with alkali, alkaline earth and toxic metal species: A dft study. J. Mol. Struct. 2017, 1130, 781-790. [CrossRef]

44. Boda, A.; Ali, S.M.; Shenoi, M.R.K.; Rao, H.; Ghosh, S.K. DFT modeling on the suitable crown ether architecture for complexation with $\mathrm{Cs}^{+}$and $\mathrm{Sr}^{2+}$ metal ions. J. Mol. Model. 2011, 17, 1091-1108. [CrossRef]

45. Liu, Z.; Zhou, Y.Q.; Guo, M.; Lv, B.L.; Wu, Z.J.; Zhou, W.Z. Experimental and theoretical investigations of Cs ${ }^{+}$adsorption on crown ethers modified magnetic adsorbent. J. Hazard. Mater. 2019, 371, 712-720. [CrossRef] [PubMed]

46. Tkachenko, N.V.; Sun, Z.M.; Boldyrev, A.I. Record low ionization potentials of alkali metal complexes with crown ethers and cryptands. ChemPhysChem 2019, 20, 2060-2062. [CrossRef]

47. Daina, A.; Michielin, O.; Zoete, V. Swissadme: A free web tool to evaluate pharmacokinetics, drug-likeness and medicinal chemistry friendliness of small molecules. Sci. Rep. 2017, 7, 42717. [CrossRef] [PubMed]

48. Daina, A.; Michielin, O.; Zoete, V. Ilogp: A simple, robust, and efficient description of $n$-octanol/water partition coefficient for drug design using the GB/SA approach. J. Chem. Inf. Model. 2014, 54, 3284-3301. [CrossRef]

49. Luk'yanenko, N.G.; Basok, S.S.; Kulygina, E.Y.; Bogashchenko, T.Y.; Yakovenko, I.S. Synthesis of monoazacrown ethers under phase-transfer catalysis. Russ. J. Org. Chem. 2012, 48, 1345-1352. [CrossRef]

50. Calverley, M.J.; Dale, J.; Jutand, A.; Nishida, T.; Enzell, C.R.; Berg, J.-E. 1,4,7-trioxa-10-azacyclododecane and some n-substituted derivatives-Synthesis and cation complexing. Acta Chem. Scand. B 1982, 36, 241-247. [CrossRef]

51. Bogatsky, A.V.; Lukyanenko, N.G.; Basok, S.S.; Ostrovskaya, L.K. Macroheterocycles; XXI. The phase-transfer synthesis of azacrown ethers. Synthesis 1984, 1984, 138. [CrossRef]

52. Lunn, W.H.W.; Podmore, W.D.; Szinai, S.S. Adamantane chemistry.I. Synthesis of 1,2-disubstituted adamantanes. J. Chem. Soc. C 1968, 1657-1660. [CrossRef] 
53. Tuemmler, B.; Maass, G.; Weber, E.; Wehner, W.; Voegtle, F. Noncyclic crown-type polyethers, pyridinophane cryptands, and their alkali-metal ion complexes-Synthesis, complex stability, and kinetics. J. Am. Chem. Soc. 1977, 99, 4683-4690. [CrossRef] [PubMed]

54. Basok, S.S.; Lutsyuk, A.F.; Kirichenko, T.I. Synthesis of azacrown ether derivatives with adamantane fragments. Visnyk Odessa Natsionalnoho Univ. Khimia 2018, 23, 26-36. [CrossRef]

55. Mlinaric-Majerski, K.; Ramljak, T.S. Synthesis and alkali metal binding properties of novel n-adamantylaza-crown ethers. Tetrahedron 2002, 58, 4893-4898. [CrossRef]

56. Basok, S.S.; Lutsyuk, A.F.; Gridina, T.L.; Fedchuk, A.S. Synthesis and antiviral activity of diaza-18-crown-6 derivatives with the fragments of 4-aminomethylbenzoic and 6-aminocaproic acids. Macroheterocycles 2018, 11, 442-448. [CrossRef]

57. Schepetkin, I.A.; Kirpotina, L.N.; Khlebnikov, A.I.; Quinn, M.T. High-throughput screening for small-molecule activators of neutrophils: Identification of novel n-formyl peptide receptor agonists. Mol. Pharm. 2007, 71, 1061-1074. [CrossRef] [PubMed]

58. Weigend, F.; Ahlrichs, R. Balanced basis sets of split valence, triple zeta valence and quadruple zeta valence quality for $\mathrm{h}$ to rn: Design and assessment of accuracy. Phys. Chem. Chem. Phys. 2005, 7, 3297-3305. [CrossRef]

59. Grimme, S.; Ehrlich, S.; Goerigk, L. Effect of the damping function in dispersion corrected density functional theory. J. Comput. Chem. 2011, 32, 1456-1465. [CrossRef]

60. Boys, S.F.; Bernardi, F. The calculation of small molecular interactions by the differences of separate total energies. Some procedures with reduced errors. Mol. Phys. 2002, 100, 65-73. [CrossRef] 